\title{
THE LIFE AND TIMES OF CAPE ADVOCATE DIRK GYSBERT REITZ: A BIOGRAPHICAL NOTE
}

\section{JP van Niekerk*}

Key words: Reitz family; Cape bar and bench in the 1820s; Batavian legal and judicial history; Orphan Chamber

\section{Introduction}

While trawling for material on the (Cape) Vice-Admiralty Court recently, I came across a reference to the following entry in the Tuesday 28 February 1854 number of the South African Commercial Advertiser and Cape Town Mail:

DIED, at Sea, near the Straits of BANKA, on the $7^{\text {th }}$ July, 1853, (on a voyage from JAVA to JAPAN), DIRK GYSBERT REITZ, Knight of the Order of the Netherland's Lion, formerly Advocate of the Court of Justice in this Colony, afterwards Member of the High Court of Justice, and judge of the Admiralty Court at Batavia, and latterly President of the Orphan Chamber at Batavia, aged FIFTY SEVEN YEARS. ${ }^{1}$

1 The reference was in transcriptions made by Sue Mackay from the Jan-Mar 1854 South African Commercial Advertiser and posted at http://www.eggsa.org/newspapers/index.php (accessed 16 Mar 2016). The announcement itself is hidden away at the bottom of the far-right-hand column on the front page of the paper, an original copy of which I traced in the National Archives (Kew), CO 53/11.

* Professor, Department of Mercantile Law, School of Law, University of South Africa. 
Although the reference to the Batavian Admiralty Court turned out to be incorrect, I realised that there was a story behind this announcement. This is it.

Emigration, banishment and exile from South Africa have been recurring themes in this country's often sad history. Locally-born lawyers, too, have been involved. Some of them attained high judicial office elsewhere, to the loss of the administration of justice here. Examples of such judicial or legal transplants in our own life-time are numerous and well known, but the phenomenon goes back to earlier times of change: to the time of the Boer Republics, ${ }^{2}$ and even further, to the British take-over of the Cape at the beginning of the nineteenth century. Dirk Gysbert (Gijsbert) Reitz is one rather obscure - but, as will appear, not the only - instance of a legal transplant from the Cape to Batavia.

\section{The Reitz family: Ascendants}

Dirk Gysbert Reitz - who was called Dirk ${ }^{3}$ - was a member of one of the several famous Cape families ${ }^{4}$ which had, from the late eighteenth century, exercised a considerable influence in local social, economic and political affairs through their land- (and slave-) ownership, commercial and agricultural enterprise, strategic intermarriage, and fortuitous inheritance. He was one of the Cape gentry. ${ }^{5}$ It should not come as any great surprise, further, that the Reitz family was one littered with lawyers. ${ }^{6}$

Dirk was the eldest son of Jan Frederik Reitz and Barbara Jacoba van Reenen.

His father, Jan Frederik, was born in Utrecht in the Netherlands in June 1761. He made a career as an officer in the Dutch Navy. After having fought against the English in the naval battle at Dogger's Bank in August 1781 during the Fourth Anglo-Dutch War (1780-1784), ${ }^{7}$ he came to the Cape (which he had visited before) on recuperative leave in 1794 . Here he married a local girl and his anti-Batavian

2 See, eg, Schulze 2010 on Jacobus Petrus de Wet (1838-1900), who was Chief Justice of the Transvaal May 1880 to Aug 1881 and subsequently Acting Chief Justice of Ceylon May 1882 to May 1883.

3 His younger brother was called Gysbert (see at n 20 infra).

4 Other influential Cape "blue bloods" included the Cloete, De Villiers, De Wet, Eksteen, Joubert, Melck, and, importantly, the Van Reenen families.

5 See, generally, Ross 1983: 207; Dooling 2005; and Williams 2013, who points out the nebulosity of the term "gentry".

6 A rich source of information on the European and South African branches of the Reitz family is "Genealogy" $s v$ "family bosch reitz", available at http://www.kloek-genealogie.nl/Reitz.htm (accessed Nov 2015-Jan 2016). See, also, Reitz 1964; South African Genealogies 2003: 250-253.

7 In the castle at Keukenhof in the Netherlands, there is a series of three coloured engravings ("gravures") by Mathias de Sallieth, done after drawings - described as neat and accurate - by Jan Frederik Reitz, of the naval action at Dogger's Bank in 1781. They were published in Amsterdam in 1781 and 1782 and are reproduced in Brand 2010: 25-26.

8 Jan Frederik was one of three founding fathers of the South African branch of the Reitz family 
sentiments caused him to stay on after the First British Occupation in $1795 .{ }^{8} \mathrm{He}$ successfully pursued sheep farming, with his father-in-law Dirk Gysbert van Reenen in the Overberg, and whaling ventures, in partnership with Pieter Lourens Cloete whose wife was Van Reenen's niece. ${ }^{9}$ In December 1816 he was appointed the local vendue master after having served as deputy to the incumbent Francois Willem Fage ${ }^{10}$ for seven years. ${ }^{11}$ Jan Frederik requested and was granted citizenship of the colony only in 1817, no doubt in response to governor Somerset's Proclamation of 2 May 1817 by which foreigners resident locally for five or more years were granted citizenship on application and swearing an oath of allegiance to the Crown. ${ }^{12}$ Jan Frederik died intestate ${ }^{13}$ in April $1824 .{ }^{14}$

(see Pama 1983: 266).

9 See, eg, CA (Cape Archives), CO 3864/427/1 (1807) for his application for the grant of two islands to start a sealing industry; and CO 3866/533A/1 (1807) for his application, with PL Cloete and Wm Anderson, to continue their whale fishery in Kalk Bay.

10 Fagel (1768-1856), a naval officer, had like his friend Van Reenen taken part in the battle off the Dogger's Bank, after which he emigrated to the Cape. He was vendue master at the Cape from 1808 (see In re Insolvent Estate of Brink. Vendue-Commissaries v Brink (1828) 1 Menzies 434) and a member of the Court of Justice until 1814, when he returned to Holland. See, further, Schutte 1977.

11 See Theal 1897-1905 vol 11: 218-220 and 245-247. The African Court Calendar for 18181824 lists "Reitz, Johan [sic] Frederik, Commissioner of Vendues, 3 Heerengracht". For the appointments of Fagel, then Reitz, and then, in 1824, Sir Charles August Fitzroy (1796-1858, who was later governor in several colonies, including New South Wales in 1846, and then governorgeneral of Australia in 1850) and Egbert Andries Buyskes jointly as vendue commissioners, see In re Insolvent Estate of Brink. Vendue-Commissaries v Brink (1828) 1 Menzies 434. And for litigation concerning Jan Frederik Reitz in his capacity as vendue commissioner at the Cape, see MacDonald \& Another v Bell (1840) 3 Moore 315, 13 ER 129 (PC), a case on appeal against the judgment of the Cape Supreme Court delivered in 1836. Reitz had in 1817 borrowed money from the colonial government, but died in 1824 not having repaid the loan. At issue was the legal liability of Alexander MacDonald and Michael van Breda as sureties for this debt under RomanDutch civil law. See, also, Colonial Government v Fitzroy (1830) 1 Menzies 492 for the liability of the joint commissaries Fitzroy and Buyskes for the debt incurred by their predecessor Reitz.

12 See CA, CO 3908/213 (1817); Hoge 1960.

13 See CA, MOOC 8/41/53. The inventory, dated 20 and 22 Apr 1824 and drawn up under the auspices of the local Orphan Chamber, contains a detailed list of his possessions. Several items would, if their description is anything to go by, today have a considerable value as antiques. Of interest - and showing father Jan Frederik's pro-British sentiments - are two paintings of Lord Nelson, one of William Pitt, and two of naval battles. His estate also included several slaves, including the twenty-seven-year old "Adonis van de Kaap", a domestic slave who was described as spoken for to DG Reitz ("die ... aan DG Reitz ... is bespooken") for Rds1100 of which Rds300 had to be paid to his brother JJ (James), and another slave, "Hester van Mosambique", spoken for to GJ Reitz for Rds800 who in turn had to account to JJ Reitz for an amount of Rds200. For Jan Frederik's estate accounts, see, further, CA, NCD 1/1/32/1 (1795), MOOC 7/1/94/73 (1795), and MOOC 7/1/94/73 (1795). For one of his slave dealings, see CA, NCD 1/40/385/1 (1799).

14 His death resulted in a rearrangement of the office of, as it had become known, the commissary of vendues: see Theal 1897-1905 vol 17: 267.

15 The University was established in 1636 and was preceded by the Hieronymusschool (1474-1578) 
But Dirk's earlier ascendants were no less illustrious. A line of them had served in the University of Utrecht: ${ }^{15}$ Johan Friedrich (Joannes Fredericus) Reitz, his greatgrandfather, a medical doctor and professor in history, oratory and poetry, later became deputy rector from 1725 to 1728 and rector from 1728 to $1748 ;{ }^{16}$ and his grandfather, Gysbert (Gijsbertus) Reitz (1731-1809), was at first an advocate and later a merchant in Utrecht.

Jan Frederik Reitz married Barbara van Reenen (1777-1818) in Cape Town in March 1795. She was the eldest child of Dirk Gysbert van Reenen (1754-1828), a prominent landowner, merchant and pioneering farmer at the Cape. ${ }^{17}$ Like the Reitzes, the Van Reenen family played a central, if not always uncontentious, ${ }^{18}$ role in Cape political and economic affairs at the end of the eighteenth and beginning of the nineteenth centuries. ${ }^{19}$

\section{The Reitz family: Descendants}

\section{Jan Frederik and Barbara Reitz had six children.}

Dirk Gysbert was the eldest. More about him shortly.

Next came Gysbert Jan Carel (1797-1859). After returning to the Cape from his ten-year-long education in the Netherlands, Gysbert occupied several minor government posts as a clerk and sworn translator ${ }^{20}$ before he commenced practising

and the Hoogeschool (1578-1636).

16 Other relations with a connection to the University included Joannes Henricus Reitz, who was deputy rector (1737-1748) and rector (1748-1769), and Jan Frederik Reitz, who was a tutor (17571769) and rector (1769-1801). See, further, Ekker 1864 Deel 2: 31-39 for a description of their terms of office; De Vries 1786: iii, xiii, xvi.

17 See, eg, Blommaert \& Wiid 1937, concerning the travels into the interior undertaken in that year by governor Janssens whom Van Reenen accompanied; it is observed at 5 that "die lotgevalle en wedervaringe van hierdie familie gedurende ongeveer die jare 1775-1825 is ' $n$ mikrokosmos van die Kaapse geskiedenis van daardie tyd".

18 Barbara's grandfather, Jacobus van Reenen (bap May 1727, d Aug 1793), was the senior member of the Cape Patriot delegation of four sent to the Netherlands in 1779 to complain to the Lords Seventeen about the Company rule at the Cape. See, generally, Beyers 1967: 27-28 and 113-115.

19 On other prominent members of the Van Reenen family, see Wagenaar 1976: esp 1-15. The journal kept by Jacobus van Reenen (1755-1806, the brother of Dirk Gysbert) on the expedition in search of the wreck of the Grosvenor was published as Jacob van Reenen and the Grosvenor Expedition of 1790-1791 (Cape Town, 1927) and translated and annotated by PR Kirby as The Wreck of the Grosvenor (Johannesburg, 1958). See, further, on the Van Reenen clan, Burrows nd: 291-292; Burrows 1994: 123-125 (containing genealogical tables and further information illustrating the kinship between the Van Reenen, Reitz, Barry and Van Breda families); and on the founding father, Jacob (d 1764), see George 2011: 52-55.

20 For his request to act as a sworn translator, see CA, CO 3916/531 (1819). He is mentioned in the African Court Calendar as one of the sworn translators for the periods 1820-1825 and 1827.

21 For advertisements concerning his legal practice, see, eg, 7 Feb 1824 and 8 Jul 1825 Cape Town 
as an attorney and notary. ${ }^{21}$ In 1830, after the unexpected premature death of his first wife and his remarriage, ${ }^{22}$ he returned to Holland and enrolled as a theology student at Leiden. After graduating, he moved to Heidelberg in Germany for the education of his children. ${ }^{23} \mathrm{He}$ returned to the Cape in 1848 and settled in Stellenbosch. Although qualified as a dominee, he was never appointed to a congregation. ${ }^{24}$

Their third child was daughter Aletta (Letje) Catharina (1798-1871). In April 1820 she married Cape advocate Joshua Andries Joubert (1793-1830) in a double wedding ceremony also involving her brother Gysbert and Joubert's sister Hester. ${ }^{25}$

Jacobus Johannes (anglicised to James John) Reitz (1801-1824) was the fourth child. Like his father, James chose a naval career, albeit in the Royal Navy. In 1824, while employed on a naval survey of the east coast of Africa and in operations against Arab slavers operating there, lieutenant James Reitz, then also appointed civil governor of Mombasa, ${ }^{26}$ died of a malignant fever, probably malaria. He was still a bachelor. ${ }^{27}$ The administration of his deceased estate subsequently became the subject of litigation in England. ${ }^{28}$

Gazette. He may have been the Reitz involved in Reitz v Kock (1828) 1 Menzies 38 and 56.

22 He had married Gesina (Geesje) Wilhelmina Karnspek (1802-1828), the great granddaughter of Pieter van Rheede van Oudtshoorn, appointee governor of the Cape, in Apr 1820. His second wife was Hester Susanna Joubert (1797-1884), younger sister of his brother-in-law, advocate JA Joubert (about whom more at $\mathrm{n} 48$ below), whom he married in Dec 1829.

23 His son, Jan Frederik (1821-1896), became a dominee in Somerset West (1848-1890) and married Martha Jacoba Catharina Hester Maria van Ryneveld, the daughter of Cape advocate HR van Ryneveld (about whom more at n 46 below), in 1847; another son, Jan Daniel Karnspek (18221892), became a Cape Town attorney and notary; his daughter, Johanna Catharina Henrietta (1828-1865) married Aegidius Benedictus Watermeyer (1824-1867), later to become a judge on the Cape Bench, in Dec 1848; and another son, Gysbert (1832-1910), became an attorney in Riversdal.

24 See, further, George 2011: 52.

25 See n 22 supra. After Joshua's death, Aletta, in Mar 1834, married the widower reverend Tobias Johannes Herold (1788-1857), a dominee in Stellenbosch.

26 After his death, the inland harbour of Port Reitz at Mombasa and Point Reitz at Kilindini harbour were named after him by naval surveyors in his squadron.

27 On James Reitz, see, further, Gregg (1952); Burrows (1959).

28 See In the Goods of John Reitz (1831) 3 Hagg Ecc 766, 162 ER 1337, from which it appears that although he had left three brothers and a sister behind, (only) two of his next of kin were still at the Cape in the latter half of 1825 and they were involved in placing his affairs under the management of the local Orphan Chamber. (Brother Dirk was then no longer at the Cape, (see, further, at $n$ $81 \mathrm{f}$ below) for otherwise he would, by reason of his qualifications, certainly have been involved.) James had made a will (which is in the National Archives, Kew, PROB 11/1796/119 (will of John James Reitz (1832)) bequeathing his estate in England - property worth some $£ 220$ - to a "miss Stanley" of whom nothing is known. The legal dispute arose because James had failed to appoint an executor for his estate. When Capt Owen, his commanding officer, passed through Cape Town in 1825 on his way back to England, James's elder brother (probably Gysbert and not Dirk) and his sister authorised him, through the mediation of the Orphan Chamber, to collect his property, settle his debts to his [naval?] agent, one Stilwell, and pay over the balance to Miss Stanley. The Prerogative Court in London refused to allow this, for strictly legal reasons, and eventually James's agent was granted the administration and, presumably, Miss Stanley received her inheritance.

29 He was named after Francois Willem Fagel, his father's predecessor as vendue master (see again n 
The fifth child Pieter Lourens (1805-1806) died young.

The last child of Jan Frederik and Barbara Reitz was Francis (Frank) William ${ }^{29}$ (1810-1881). ${ }^{30}$ A polyglot, pioneering farmer (with his father) and agriculturalist (he imported the first Merino sheep to the Cape and wrote a pamphlet Observations on the Merino in 1834), and politician (a member of parliament for Swellendam in 1869, Usher of the Black Rod in the Cape Parliament), Frank was by far the most prominent of the Reitz children. In March 1832, he married Cornelia Magdalena Deneys (1813-1893), the granddaughter of Johanna Catharina Deneys who had married and was the second wife of Dirk Gysbert van Reenen. The couple had twelve children. Their seventh child, and third son, was Francis William (1844-1934), Cape advocate (1868-1874), Chief Justice (1875-1888) and later President (1889-1896) of the Orange Free State, judge of the Transvaal High Court (1898), State Secretary of the Zuid-Afrikaansche Republiek (1898-1902), and ultimately, after a period of voluntary exile, first President of the Union Senate (1910-1920). ${ }^{31}$

\section{$4 \quad$ Early years and study}

Dirk Gysbert Reitz was born in Cape Town on 29 January 1796, a few months after the British had taken over the settlement from the Dutch East India Company. Like so many other children of the local landed gentry, he was destined to be educated in the Netherlands. As a nine-year old boy, Dirk and his younger brother Gysbert were taken by their father to Europe for that purpose. His sojourn in northern climes was prolonged, for Dirk only returned to the Cape as a twenty-three-year old, in 1819. ${ }^{32}$

Not surprisingly, given the family connections and the fact that several other Cape natives had studied there, ${ }^{33}$ the boys went to Utrecht where Dirk ended up studying law.

10 supra) who was likewise a former Dutch naval officer, and was further also a one-time member of the Court of Justice.

30 On him, see JCM 1972; George 2011: 53-55.

31 On FW Reitz jnr, see Kitchin 1916; Moll 1978; and JCM 1972. President Reitz, too, had some notable offspring, the best known of whom was probably his third son, Deneys Reitz (1882-1944), soldier, attorney, politician and author of the autobiographical trilogy Commando: A Boer Journal of the Boer War (published in 1929), Trekking On (1933), and No Outspan (1943). On him, see AL-S 1968.

32 See George 2011: 52. In South African Genealogies 2003: 250 it is observed that while studying abroad, Dirk served in "die Nederlandse ruitery tydens die Napoleontiese oorlog".

33 Cape predecessors of Reitz at Utrecht who had studied law include (with the titles of their theses) Daniel Petrus de Mauregnault Dissertatio juridica inauguralis de poena cogitationis ad L XVIII D de poenis (1762); Jaques le S(e)uer Dissertatio juris publici Belgici inauguralis de jure indemnitatis (1757); Jacobus Petrus Deneys Disputatio juridica inauguralis de cadaveribus punitorum (1762); and (also under Herman Arntzenius: see n 35 below), Johannes Carolus Leseuer Dissertatio juridica inauguralis continens quasdam juris civilis quaestiones (1796). This information comes from the online Digitaal album promotorum Universiteit Utrecht (accessed 14 Jan 2016) passim. 
At the time, Dirk's lecturer and promoter ${ }^{34}$ was Herman (Hermannus) Arntzenius (1765-1842), a professor in law at the University of Utrecht. ${ }^{35}$ Youngest son of the now better known Hendrik Jan (Henricus Johannes) Arntzenius (1734-1797), ${ }^{36}$ he graduated at Groningen in 1798 and was appointed to the professorial chair at Utrecht in July 1800, a post he occupied until November 1815, after which he became a "gewoon hoogleraar" until his retirement in February 1835. He lectured in Roman law, Dutch civil law (ius hodiernum), and public law. ${ }^{37}$

Dirk Reitz - referred to in the University's academic graduation records as "Reitz, Didericus Gysbertius", "natus in Promontorio Bonae Spei" - graduated on 11 October 1817 under the supervision of professor Herman Arntzenius. ${ }^{38} \mathrm{He}$ did so not on the basis of a thesis, but on "stellingen" alone..$^{39}$

After graduation, Dirk Reitz returned to the Cape. ${ }^{40}$

\section{$5 \quad$ Reitz at the Cape bar}

Reitz practiced as advocate at the Cape from sometime in 1819 until the early part of 1824 , a period of no longer than five years. ${ }^{41}$ The local bar was small, its numbers

34 Other law lecturers at Utrecht during Dirk Reitz's time there, were Cornelis Willem de Rhoer (professor 1797-1822) and JR de Brueyns (professor 1815-1848). Van den Bergh, Spruit \& Van de Vrugt 1986: 9 explain that until 1830, the Utrecht law faculty, which was established in 1636, as rule had two or three professors at a time.

35 On the University of Utrecht, its faculty of law and the Arntzeniuses, see Van den Bergh, Spruit \& Van de Vrugt 1986: passim, esp 9, 16-17, 19 and 220 (pointing out (at 19) that between its establishment in 1636 and 1814, on average of twenty-five jurists graduated annually at Utrecht and that there had only been 133 law professors in 350 years); Ahsmann 1993: 55-63.

36 Hendrik Arntzenius was first professor in Groningen, and then taught Roman law and later international law in Utrecht (1788-1797). He was the author of Institutiones juris Belgici civilis de conditione hominum, 3 vols $(1783,1788,1798)$, which was translated by FP (Toon) van den Heever in 1963 as Introduction to the Civil Law of the Netherlands. The view of Roberts 1942: 39 that the posthumous vol 3 was prepared for publication by his eldest son, Hendrik Jan jnr (17631830), who was also a lawyer, is doubted in the preface to the translation, but is supported by Ahsmann 1993: 60.

37 See, further, Van den Bergh, Spruit \& Van de Vrugt 1986: 12, 220. There is a reproduction of his likeness in Digitaal album promotorum Universiteit Utrecht (accessed 14 Jan 2016).

38 See Digitaal album promotorum Universiteit Utrecht (accessed 14 Jan 2016) sv "Reitz".

39 Van den Bergh, Spruit \& Van de Vrugt 1986: 9 explain that in the eighteenth century at Utrecht, the main examination ("meestersproef") for a doctorate still consisted of delivering a lecture ("een proefcollege") on two texts. Teaching by means of public lectures (lectiones) had fallen out of favour by the beginning of the nineteenth century, and was largely replaced by private instruction and tuition at the home of a professor (collegia) and by weekly (student-presented) disputations (disputationes) on topics prescribed by the professor (idem at 16). The latter prepared students for the formal, public (in the senate hall) defence of their disputatio pro gradu by which the doctorate was obtained (idem at 17).

40 The permission mentioned in Theal 1897-1905 vol 9: 496 that was given in Apr 1814 in London for a "Mr Reitz" to proceed to the Cape was probably not for him.

41 He is mentioned as a member of the bar in the African Court Calendars of 1820-1824. As these annual volumes were compiled shortly before and published at the beginning of each year, it means that he commenced practice before the beginning of 1820 , but had left before the end of 
growing from six to eleven members during this period. At the time, and in fact since the Batavian period and until the British legal reforms of 1828 , persons who had been born in the colony or who had a right of residence there, and had graduated in law at one of the universities or gymnasia in Holland, were qualified to be admitted to practice as an advocate..$^{42} \mathrm{~A}$ contemporaneous account of the Cape described them as "Cape-born, the sons of gentlemen from Holland, or Germany, settled in the colony, who have been educated in Holland. There are amongst them, men of attention and talents". 43

So, who were Reitz's colleagues practicing before the Cape Court of Justice?

The most senior advocate when he joined the bar was Dr Hendrik (Henry) Cloete (1792-1870). ${ }^{44}$ A member of a leading Cape family, ${ }^{45}$ with a doctorate from Leiden in 1811, under Van der Keessel no less, Cloete was admitted to the English bar in 1812. He commenced practising at the Cape in 1814 after he had been the deputy secretary of the Court of Justice since 1813. He remained a member of the bar until 1843. In that year he was appointed special commissioner for Natal. After the annexation of that territory in 1845, he was appointed Recorder and sole Judge of Natal, a post he occupied for a little more than ten years. Thereafter he became a puisne judge in the Cape from 1855 until 1866.

Next in line of seniority was Helperus Ritzema van Ryneveld (van Rijneveld), an advocate from 1815, likewise with a Dutch doctorate. ${ }^{46} \mathrm{He}$ remained in practice after the reforms of 1828. Then came Michiel Adriaan Smuts who practiced from 1815 until 1827 and was also a notary from $1815 .{ }^{47}$ In 1828 , he was admitted as an attorney. ${ }^{48}$

1824. He is mentioned in the directory of the Calendars (as "Dirk Gysbert Reitz, advocate, at 3 Kerkplein"), but only in 1820 and 1821.

42 On the Cape bar, see, further, generally Botha 1924; Visagie 1969: 48-52 (up to 1795) and 106108 (legal practitioners during the Batavian period); Farlam 1988; Van Huyssteen 1989; Erasmus 2015: 221-223, for the period before 1828. Further information on the individual members of both the bar and the bench were gathered from the relevant volumes of the African Court Calendar.

43 Bird 1823: 11.

44 On Cloete, see Roberts 1942: 353; Cloete 1934; AFH 1968b.

45 He was the son of Pieter Lourens Cloete (see n 9 supra), vice-president of the Orphan Chamber, and grandson of Hendrik Cloete, the owner of the farm "Constantia" from 1778.

$46 \mathrm{He}$ has to be distinguished from Willem Stephanus van Ryneveld (1765-1812), a Company official, fiscal, and member and later, from 1809, president of the Court of Justice until his suicide in 1812 (see HBG 1972b), and from Daniel Johannes van Ryneveld, a member of the Court in 1814.

47 See the Inventory of the Notarial Archives of the Cape of Good Hope, 1790-1879, inventory no 1/7/1 item U. There was also a notary in 1814-1815 called Johannes Joachim Lodewyk Smuts: idem, inventory no $1 / 7 / 1$ item $\mathrm{T}$.

48 Botha 1924: 259, 261 points out that although notionally separate professions, advocates and attorneys could also practice as notaries, at least until 1806. However, that changed in 1812 when the professions were separated and in 1817 an application to the governor to be admitted as a notary was refused on grounds that the applicant was already an advocate. See, further, Wildenboer 2010. 
Josua Andries Joubert (1793-1830), who had graduated in Leiden, was an advocate from 1817 and remained on as such after 1828. He married Reitz's sister Aletta Catharina in 1820, in double wedding ceremony in which their brother, Gysbert Jan Carel, married Joubert's younger sister, Hester Susanna. Joubert was another of the old advocates who stayed on after 1828. Also at the bar was Oloff Marthinus Bergh, an advocate from 1817, likewise a notary ${ }^{49}$ and member of a leading Cape family. ${ }^{50}$ The last of the six advocates in practice when Reitz joined was Johannes Jacobus Lind, another Dutch doctor of law, who had also been in practice from $1817 . .^{51}$

During Reitz's attachment to the Cape bar, only five more advocates joined.

First, in 1820, was Abraham Faure (1795-1868), a doctor in law and member of the illustrious Faure family. ${ }^{52}$ In the next year Christoffel Joseph Brand (17971875) joined. Of all Reitz's fellow advocates, Brand was destined to have the most prominent legal career. The son of the legally unqualified Johannes Hendrikus Brand, who was a member of the Court of Justice from 1825 to $1827,{ }^{53}$ he was called Joseph after his godfather, sir Joseph Banks, who visited the Cape with captain Cook in 1771 and became a good friend of the family. With doctorates in $1 \mathrm{w}^{54}$ and literature obtained from Leiden in 1820, and having been admitted to the English bar, Brand soon rose to prominence as one of the leading practitioners at the local bar. He had a long and illustrious legal career, and was also intermittently active as a journalist (he was editor of De Zuid-Afrikaan) and politician (he became the first speaker of the Legislative Assembly of the Cape in 1854). ${ }^{55}$

Two further members joined in 1823. The one was Johannes A de Wet, also a Leiden graduate, ${ }^{56}$ father of Maria Margaretha (Marie) Koopmans-De Wet (1834-

49 Inventory of the Notarial Archives of the CoGH, 1790-1879, inventory no 1/7/1 item AP.

50 He was possibly the son of Marthinus Adrianus Bergh (1747-1806), a Company official, one of the Cape Patriot movement, and landdrost of the Stellenbosch and Drakenstein districts from 1773 to 1778, and the grandson of Olof Martin(i) Bergh (1722-1795): see, further, JP 1968.

51 He should be distinguished from his brother Franciscus Xaverius Lind, a notary from 1817 to 1824 (see Inventory of the Notarial Archives of the CoGH, 1790-1879, inventory no 1/7/1 item Z), and Christian Michael Lind, a notary from 1822 to 1843 (idem, inventory no 1/7/1 item AE).

52 He was the cousin of his namesake Abraham Faure (1795-1875), a dominee. Advocate Abraham's son was dominee DP Faure: see HAH 1968; one Pieter Hendrik Faure was a notary from 1793 to 1795: see Inventory of the Notarial Archives of the CoGH, 1790-1879, inventory no 1/7/1 item B.

53 Brand's grandfather Christoffel (1738-1815) was, like his father Johannes Hendrikus (17711835), also a member of the Court of Justice: see AEB 1968.

54 With a thesis entitled Dissertatio politico-juridica de iure colonarium ...

55 His eldest son, JH Brand, who was also an advocate, became fourth president of the Orange Free State. On Brand snr, see HCB 1968.

56 His doctoral thesis of 1821 was entitled De usucapionne et praescriptione secundum principia juris Romani. He should be distinguished from Olof Godlieb de Wet (1739-1811), a member of the Court of Justice from 1778 to 1803 and again from 1807 to 1809 (see M Po 1972), and from Jacobus Petrus de Wet, likewise a Leiden graduate and a local advocate from 1804 and notary from 1807. 
1906), ${ }^{57}$ related by marriage to several other Cape legal luminaries,${ }^{58}$ journalist and businessman, ${ }^{59}$ and later a member and in 1857 president of the Cape Legislative Council. ${ }^{60}$ The other was JH Hofmeyr, another Leiden graduate. Finally, in 1824, AC Mom Faure joined the bar, although he may have done so after Reitz had already left. What of the Court of Justice, before which these men practised?

As is generally known, this body's nine members were not required to be legally qualified, a defect seen to justify severe criticism and even derision from the British authorities and those advocating the reform of the local administration of Dutch justice. ${ }^{61} \mathrm{~A}$ familiar problem, even then, was that not many practicing lawyers, including advocates, were willing to be appointed as members of the bench as that inevitably involved a loss of income. Nevertheless, legal experience was not totally

57 See Vollgraaff 2004: 132.

58 His sisters had married Judge John Truter (see n 63 infra), advocate (and later judge) Johannes Neethling (see n 67 below), and advocate Daniël Denyssen (Denijssen). The latter (1777-1855), also a Leiden doctor in law, was a judge during the Batavian period, and an advocate during the British regime. In 1812, when fiscal Truter was appointed to preside over the Court of Justice, Denyssen was appointed in his place and was the last person to occupy the contentious position of fiscal (crown prosecutor), which he continued to do until his retirement in 1828, after which he resumed practice before the Supreme Court. See, further, Kotzé 1977. His son, Petrus Johannes Denyssen (1811-1883), also an LLD from Leiden, was admitted as an advocate at the Cape in 1837 and later became a judge in the Eastern Districts and the Cape. See, further, Anon 1903; Quinton 1987.

59 He founded De Zuid-Afrikaan with fellow advocate CJ Brand and Judge JH Neethling and managed it for a few years. He gradually paid less attention to his legal practice and increasingly devoted his attention to the affairs of the Association for the Administration of Estates which he had founded in 1836.

60 On De Wet, see RFMI 1968.

61 For contemporaneous criticism of the Cape legal system and administration, see, eg, Bird 1823: 9-14, stressing the lack of judicial independence from the government, mainly the result of the peculiarities of the inherited office of the fiscal, and the absence of a jury system. The lack of legal training and the general incompetence of local lawyers, too, were a problem: Bird observed that the local advocates, although better trained, were more (but not as much as the local attorneys!) interested in financial gain than in the administration of justice. Additional objectionable features were the anachronous fact that Dutch law and procedures were applied by Dutchmen to Englishmen in what was now, after all, "their colony", and that the use of Dutch was still prevalent in judicial proceedings. Bird concluded (at 13) that even if Dutch law was to continue to be the applicable law for the time being, "there cannot be a doubt in any man's mind, now that the colony is British, that decisions of the court of justice, and the arguments of the advocates, ought to be carried on in the English language at a very early day; and that the advocates and chief justice, on any future admission, should be barristers of an English court". These criticisms were reflected in later reports that lead to the judicial reforms of 1828, most pertinently in the report and recommendations in 1823 of the Commission of Eastern Enquiry under Bigge and Colebrook that resulted in fundamental changes to the Cape judicial system in 1828. See further, eg, Cowen 1959: $2-5$, referring to the criticisms of contemporary, invariably British, commentators (administrators, inhabitants, settlers or travellers) on the administration of justice at the Cape prior to 1828 . 
lacking and some of the thirteen members who served during Reitz's time at the bar were in fact trained lawyers. ${ }^{6}$

President Johannes Andreas (later Sir John Andrew) Truter had a Dutch doctorate, ${ }^{63}$ as had members Willem (William) Hiddingh, ${ }^{64}$ Daniel Frederik Berrangé, ${ }^{65}$ Walter Bentinck, ${ }^{66}$ and Johannes Henoch Neethling. ${ }^{67}$

62 See Van Huyssteen 1994: 359 who observes that "most legal practitioners at the time were (probably) trained in Roman-Dutch law, as well as [were] most of the members of the Court of Justice".

63 He graduated from Leiden in 1787 with a thesis entitled De regula civilis juris hereditarii: a semet ipso non legatur. Truter's father, Hendrik Andreas (Andries) Truter (1737-1814), was likewise a member of the Court of Justice, including at a time when Truter fils was its secretary from 1793 to 1803. Truter jnr was subsequently secretary of the Council of Policy during the Batavian period from 1803 to 1806 , then practised as an advocate from 1806 to 1809 , and was then appointed as fiscal (prosecutor) from 1809 to 1812. In Aug 1812, Truter became president of the Court (as the Council had become known) of Justice. Sir John (he received his knighthood in 1820, the first native to be honoured in this way) retired on pension in 1828. He married one of the sisters of advocate Johannes de Wet and one of their sons, Johannes Andreas Truter, also obtained his doctorate at Leiden. On Truter, see, further, Roberts 1942: 379; Botha 1918; BB 1968; Heese 1981a. On Truter's son, Oloff Johannes Truter (1797-1867), who, after an early career as a civil servant, became an attorney (he was admitted in 1828) and notary, see Nilant \& Potgieter 1981 and cf Orphan Chamber v Truter, Attorney (1830) 1 Menzies 452.

64 Born in the Netherlands, Hiddingh (1773-1839) obtained a doctorate from the University of Groningen in 1794. After a stint in practice, he emigrated to the Cape during the Batavian period where he became a member of the Court of Justice in Mar 1803, serving until its demise in Dec 1827. He married Anna Margaretha, a daughter of Cornelis van der Poel (1734-1804) who was a member of the Council of Policy from 1777 to 1780. Willem Hiddingh's namesake father (17301788) likewise held a doctorate in law and was a practising advocate in the Netherlands, while two of Willem's sons were also lawyers, both Groningen doctors: Cornelis (1809-1871) was a jurist in the Netherlands and later consul-general there of the Orange Free State (a bibliophile, Cornelis and his co-benefactor Sir Donald Currie are commemorated in the Hiddingh-Currie Publication Fund, established at Unisa), while Willem jnr practised at the Cape bar from 1833 after a period in practice in Scotland. See, further, JCV 1968; Heese 1981b; FJuTS 1968.

65 Berrangé (1775-1845), who returned to the Cape with a Dutch doctorate in 1802, occupied several judicial or semi-judicial posts at the Cape: deputy fiscal (in 1806), member (in 1813) and later secretary of the Court of Justice (1819-1827), president of the Orphan Chamber (in 1828), and master of the Supreme Court (1833-1834). An expert on the Dutch legal system, and a champion of Afrikaans, Berrangé was co-responsible for the "codification" of all existing Cape statutes. He was the younger brother of Jan Christoffel Berrangé (1769-1827), a Cape minister of religion and moderator of the first Dutch Reformed Church synod. Their mother, Elizabeth Fleck, was the sister of the reverend Christiaan Fleck and Judge Abraham Fleck. See, further, Potgieter 1981 and HCH 1968. Berrange's predecessor as secretary of the Court, from 1806 to 1817, Jonkheer Gerard (Gerrit) Beelaerts van Blokland (1772-1844), was also an LLD: see, further, FGEN 1968.

66 He was a member of the Court from 1814 to 1825.

67 Neethling (1770-1838) graduated at Leiden in 1791 and then returned to the Cape. He was said to have considered a legal career in Batavia, a plan scuppered by the death of his father at the Cape and his own illness on the voyage home. He was appointed deputy fiscal at the Cape in 1793, practiced as an advocate and notary from 1795 to 1803 , was a member of the Council of Justice during the Batavian interregnum 1803 to 1806 , returned to practice as advocate and notary from 1806 to 1815, and was then persuaded to once again becoming a member of the Court of Justice, which position he held until the end of 1827 . These occupational shifts were all politically motivated. In 1828, when the Supreme Court replaced the Court of Justice, he again returned to practice, one of the few not to retire but to bridge both eras. Related to advocate Denyssen and Judge Truter (all three married sisters of advocate JA de Wet: see again n 58 supra), Neethling was 
Members of the Court while Reitz practised before it who were not qualified or trained lawyers, were Clement Matthiessen, ${ }^{68}$ William David Jennings, ${ }^{69}$ Frans Reinhard Bresler, ${ }^{70}$ Johannes Christiaan Fleck, ${ }^{71}$ Petrus Stephanus Buissinné, ${ }^{72}$ Petrus Johannes Truter, ${ }^{73}$ Petrus Borchardus Borcherds,${ }^{74}$ and Ralph Rogerson. ${ }^{75}$ But even so, some of them had no doubt gained considerable practical judicial experience under the tutelage of their qualified brethren and they naturally had the benefit of the learned arguments of the legally qualified advocates appearing before them. It should also be remembered that the quorum of the Court (five members in civil and seven in criminal appeals) meant that in practice it was seldom if ever comprised solely of unqualified members.

While the newly established Supreme Court was manned by four imported, English-trained judges, none of whom could be reckoned amongst the leading legal lights of their time ${ }^{76}$ of the nine who were in January 1828 admitted to practise as

a co-founder (with De Wet and advocates CJ and PA Brand) of De Zuid-Afrikaan. See, further, Kotzé 1981a.

68 Who was a member from 1806 to 1823.

69 Who was a member from 1813 to 1819.

70 Bresler (1766-1825) was a member of the Court from 1815 to 1825 . He had been the landdrost at Graaff-Reinet, from 1795, and deputy receiver-general from 1804 to 1815 . He committed suicide in Mar 1825 when a commission of inquiry discovered that money he had received in 1814 while receiver-general had never been paid over to the treasury. See, further, HBG 1972a.

71 A son of Cape dominee Christiaan Fleck (1756-1820), JC was a member of the Court from 1817 to 1827. See, further, Kitshoff 1977. There was also a notary called Johannes Christoffel Fleck from 1815 to 1855: see the Inventory of the Notarial Archives of the CoGH, 1790-1879, inventory no $1 / 7 / 1$ item $\mathrm{V}$.

72 He was a member from 1819 to 1823 , when he was accused of fraud: see, further, at $\mathrm{n} 79$ infra.

73 A Dutch-qualified medical doctor, and after a stint as chief customs officer in Simon's Town, Truter (1775-1867) was a member of the Court from 1819 to 1827 . He was the second son of civil servant Petrus Johannes Truter snr (1747-1825). His sister Anna Maria was married to the traveller and writer John Barrow and Chief Justice JA Truter was a cousin. See, further, Kotzé $1981 b$.

74 Borcherds (1786-1871) was a member of the Court from 1823 to 1827 after earlier quasi-judicial and civil appointments (clerk to the Court from 1803, district secretary of Stellenbosch from 1809, deputy fiscal from 1812). After the reforms of 1828 , he continued to occupy various public offices (superintendent of police, first resident magistrate of the new Cape district and, from 1834, civil commissioner of the Cape division too). See, further, HCH 1972.

75 Who was a member from 1823 to 1827.

76 As Sachs 1973: 38 observes, each probably had strong personal motives for taking up a relatively lucrative appointment at the remote but climatically healthy Cape Colony: Menzies had allegedly killed a man in a duel; Wylde was probably trying to get away from his wife whom he had left behind in New South Wales - she only arrived at the Cape in 1835, ten years after the couple had last seen one another, accompanied by a six-year-old daughter; soon after they were divorced: see Wylde $v$ Wylde (1835) 1 Menzies 269 - and was also allegedly involved in an incestuous relationship with his eldest daughter, Jane Elizabeth (see, further, McKenzie 1999); Burton was a wandering sailor turned lawyer whose globetrotting eventually took him to five continents: he was transferred to New South Wales in 1832; and Kekewich of the local Vice-Admiralty Court had earlier in his capacity as an assessor on the local Court of Appeals for Criminal Cases essentially been a legal advisor to the colonial government in the person of that Court's presiding officer, the governor. 
advocates before it, seven had practised before or were members of the old Court of Justice: Neethling, Cloete, Van Ryneveld, Joubert, Brand, De Wet, and Hofmeyr. ${ }^{77}$ Also then admitted were the former fiscal Denyssen and the newly arrived Englishman Saxe Bannister. ${ }^{78}$ Their colleagues Bergh and Faure were admitted in February and March of the same year. Clearly the link with the previous regime remained, despite the concerted efforts at renewal and reform. And, it may be thought, that was at least in part the case because those involved were more than qualified to practice as advocates, even before a revamped and anglicised Supreme Court.

Be that as it may, even in Reitz's time at the Cape bar, local legal practice was far from one being dominated and run by unqualified amateurs. Take one example, in which Reitz was involved in November 1823 as the advocate defending Petrus Stephanus Buissinné. Until recently a member of the Court of Justice, ${ }^{79}$ Buisinné was accused of fraudulent dealings involving the embezzlement of public funds during his earlier tenure as the receiver of land revenue. In addition to Reitz, the prosecuting fiscal (Denyssen), three of the members of the Court (Truter, Hiddingh, and Neethling), and its secretary (Berrangé) were all doctors of law! ${ }^{80}$

\section{Leaving the Cape}

Dirk Reitz left the Cape for Batavia in 1824. In the Cape Town Gazette and African Advertiser of Saturday 5 June 1824, "being on the eve of leaving the Colony", advocate Reitz placed an advertisement requesting that all claims against him should be sent to his agent $\mathrm{G}$ (ysbert) Reitz. ${ }^{81}$ Certificates were issued by various local

77 See Phillips 1980: five for the list of ten advocates and eleven attorneys who were in practice in 1829. The attorneys were PJ Truter, PA Poupart, OJ Truter, JP de Wet (LLD), MA Smuts, R Beck, JS Merrington, C Whitcomb, G Cadogan, J Sturgis, and L Whitham.

78 Bannister (1790-1877), formerly attorney-general of New South Wales, arrived in 1827 and was an advocate at the Cape only until Jul 1829: see AFH 1968a.

79 See n 72 supra.

80 For the proceedings, see Theal 1897-1905 vol 31: 476-518. Buissinné was found guilty of embezzlement, with the aggravation of perjury, and banished from the colony for seven years. Reitz noted an appeal to the Court of Appeal for Criminal Cases, which confirmed the guilty verdict, but found no proof of perjury. Buissinné's estate was sequestrated in Oct 1823 and was the subject of subsequent litigation: see In re Insolvent Estate of Buisinné. Van der Byl \& Meyer v Sequestrator and Attorney-General (1828) 1 Menzies 318 and In re Insolvent Estate of Buisinné. Croeser v Sequestrator and Attorney-General (1829) 1 Menzies 330. Both judgements involved a detailed analysis of the relevant Roman-Dutch authorities, and for which the Court was no doubt deeply indebted to the appellants' advocates, Joubert and Cloete.

81 Many sources have it that he left in, or only in, 1829: "Genealogy" sv "family bosch reitz" available at http://www.kloek-genealogie.nl/Reitz.htm (accessed Nov 2015-Jan 2016) has 13 Jun 1829; in Digitaal album promotorum Universiteit Utrecht (accessed 14 Jan 2016) sv "Reitz" it is mentioned that after graduation he became an advocate at the Cape and then emigrated to Batavia in 1829. FW Reitz in his Outobiografie (Moll 1978: 5) has 1822, which appears clearly wrong. It is possible that he may have left in 1824, returned to the Cape briefly afterwards, and then again returned for good to Batavia, possibly in 1829. I could find no firm evidence of this. The archival reference to the record of proceedings in litigation involving Michiel van Breda, Josua Andreas Joubert, Gysbert Jan Carel Reits and Dirk Gysbert Reitz as plaintiffs and Muller, Badenhorst, Crouse \& Louwrens as defendants in 1829 (CA, CSC 2/1/1/10 ref 54 (1829)) is not proof of Dirk's presence, let alone his residence, at the Cape at the time. 
officials concerning the departure of "DG Reitz, Esq, LLD" from the colony, all dated in June $1824:{ }^{82}$ by the fiscal, that Reitz had undertaken not to take unstamped letters with him; and by the secretary to the Court of Appeals, by the secretary to the Court of Justice, by the Sequestrator's Office, by the Burgher Senate, and by the Vendue Office, all stating that there were no legal objections on their part to Reitz's being permitted to leave the colony by the Dageraad. His local affairs were being wound down. ${ }^{83}$

The Dutch frigate Dageraad, captained by WA van der Hart, which had sailed from Texel in November 1823, from Flushing in January 1824, and from Elmina, on the coast of Guinea, in March, arrived in Simon's Bay on 30 April. ${ }^{84}$ She left again on 13 June, bound for Batavia ${ }^{85}$ She arrived there on 27 July, in a badly deteriorated condition, after what turned out to be her last voyage. On board was Dirk Reitz. ${ }^{86}$

Why, then, did Reitz decide to leave the Cape?

Although there may have been other, or additional, reasons, ${ }^{87}$ several sources suggest that the colonial policy of anglicisation may have been the main factor leading to his decision to emigrate. ${ }^{88}$

The initial periods of uncertainty ${ }^{89}$ about the future role of Britain at the Cape ended in 1814. British rule was formally recognised when the Cape was permanently ceded to Britain by the Anglo-Dutch treaty (also known as the London Convention) of 13 August of that year. ${ }^{90}$ Then the mainly strategic settlement became a colony

82 For the permits to leave the colony issued for Reitz, see CA, CO 6062/101 (1824).

83 In Oct 1824, advertisements appeared for the sale of a male slave named David of the Cape, aged ten years, on Thurs 14 Oct 1824, at Worcester by the sequestrator's agent there, on account of J Beesler, in execution of a sentence in favour of DG Reitz: see 2 Oct 1824 and 9 Oct 1824 Cape Town Gazette and African Advertiser.

84 See 8 May 1824 Cape Town Gazette and African Advertiser.

85 See 19 Jun 1824 Cape Town Gazette and African Advertiser.

86 Also on board the Dageraad was Jan van Speijk (1802-1831), a Dutch naval officer who subsequently became a hero in the Netherlands for his fatal opposition, in Feb 1831, to the Belgian revolution when, rather than taking down the Dutch flag as ordered, he set his own gunboat alight in the port of Antwerp. Van Speijk served a tour of duty in the Dutch East Indies from 1823 to 1825 , having been assigned to the Dageraad in May 1823. In Jan 1824, she sailed for the East Indies, via the Cape of Good Hope. En route, the Dageraad started leaking and continuous pumping was required to keep her afloat. On her arrival in the Batavian roadstead, an inspection revealed that her condition was so bad that she was no longer fit for sea service and she was then used only as a watchship. See, further, Koning 1832: 21-22.

87 Such as the fact that Reitz did not make headway in practice; however, there is no concrete published evidence of this and further archival research would be required to ascertain this.

88 See, eg, George 2011: 52, suggesting that Reitz possibly forsook the Cape as result of the anglicisation measures of Lord Charles Somerset.

89 That is, the period of the First British Occupation from 1795 to 1803 and the period after the Second British Occupation in 1806.

90 In terms of this treaty, colonial possessions in the Americas, Africa and Asia as they were in Jan 1803 at the outbreak of the Napoleonic Wars, were returned by Britain to the Dutch, with the exception of the Cape of Good Hope and a few other South American territories (that were later consolidated as British Guiana) where the Dutch retained trading rights. 
to be exploited economically ${ }^{91}$ and more permanent, long-term policies could be devised for its assimilation and incorporation into the British empire by a process of anglicisation. Such anglicisation took place on several fronts, and both formally and informally. For present purposes it is only necessary to refer to changes that had occurred or were projected in the legal administration ${ }^{92}$ and in the language policy by the time Reitz must have decided to leave.

Although the main changes were to the existing legal administration and not to the applicable legal system, advocates and other legal practitioners must have been well aware that in addition to those few changes that had occurred, further and greater reforms were on the cards, including, ultimately, the possible assimilation of the imperial British law into the existing Roman-Dutch colonial law. ${ }^{93}$ Reforms were often propagated and supported under the guise of modernisation rather than full-scale anglicisation. ${ }^{94}$

A first and fundamental step towards anglicisation in all its forms and in all areas, also in that of legal administration, was language reform. The lack of acquaintance with the English language by both trained and untrained Dutch lawyers was problematic and considered detrimental to British commercial and other interests in the colony.

After repeated suggestions and proposals that English should be, or become, the exclusive language of use in local courts, language reform, in anticipation of the reform of the administration of justice, came in the form of a Proclamation of 5 July 1822. It envisaged the adoption, on a future date, set at 1 January $1827,{ }^{95}$ of

91 Until 1814, the value of the Cape was seen more in keeping it out of enemy control for the defence and protection of India and the territory was of more commercial value to the monopolistic East India Company than to Britain herself: see McAleer 2013: esp 299-300. For the changed British attitude towards the Cape, see, also, Freund 1989: 325-256; Peires 1989: 474.

92 See Sturgis 1983 for an attempt at classification. Other areas in which (formal) anglicisation had an effect included education, religion, the civil service and local government. The process was also made all the more visible with the arrival of some 4000 British settlers from 1820, at a time when the total European, mainly Dutch population, was a little more than 40 000: see Bird 1823: 107. See, further, Bickford-Smith 2003; and also generally Dubow 2009: 4 who points out that "[b]y comparison with the other white dominions it [South Africa] was the least thoroughly anglicised and undoubtedly the most troublesome".

93 McKenzie 2015: 792 points out that even prior to the report in 1823 of the Commission of Eastern Enquiry under Colebrook and Bigge that resulted in fundamental changes to the Cape judicial system in 1828 , change had been in the air and that it was "common knowledge that a new judiciary was only a matter of time".

94 Objections were levelled, for instance, at inadequately trained judicial officers, the lack of a jury system, the harsh punishments provided for by the criminal justice system, and the supposed backwardness of Roman-Dutch commercial and procedural law.

95 The envisaged date of 1 Jan 1827 was subsequently postponed pending the restructuring of the courts, which only took effect at the beginning of 1828: see Ord 71 of 1826, entitled Exclusive Adoption of the English Language Postponed. 
English as the exclusive judicial language in all courts in the colony - it referred to the exclusive use of English "in all Judicial Acts and Proceedings". ${ }^{96}$

Although some members of the Cape judiciary and bar at the time were certainly bilingual, if not multilingual, it is not certain whether Reitz was one of those for whom English was Greek. ${ }^{97}$ His reaction to the process of judicial anglicisation, as presaged by the language proclamation, ${ }^{98}$ if such it was, was in any event stronger than that of any of his colleagues: ${ }^{99}$ he chose exile. ${ }^{100}$

Even if the reasons for Reitz's departure from Cape Town are not absolutely certain, it is probably safer to speculate on why he chose to go to Batavia.

Unlike the Cape, former East Indian territories, including Batavia, had in 1814 been returned to the Dutch. Accordingly there the application of Roman-Dutch law and the use of the Dutch language were not under threat. Also, as will appear in due

96 It further provided that all official acts and documents, excluding judicial documents and records, had to be in English only as from 1 Jan 1825. See, further, Van Niekerk 2015: 379-383.

97 McKenzie 2015: 792, pointing out that although several key members of the Cape judiciary were bilingual (eg, Truter CJ and fiscal Denyssen), "others, however, were not". FW Reitz in his Outobiografie (Moll 1978: 5-6) opined that Dirk had departed for Java in 1822 "waarskynlik omdat in dié jaar Hollands uit die geregshowe verban is en hy slegs dié taal magtig was".

98 Linguistic colonialism remained a bone of contention in the Reitz family. For instance, descendant FW Reitz 1900: 9-10, in his A Century of Wrong - described as "perhaps the most famous Afrikaner anti-imperialist polemic of the late nineteenth century" in Crais \& McClendon 2013: 169 - wrote as follows: "When the Cape was transferred to England in 1806, their language was guaranteed to the Dutch inhabitants. This guarantee was, however, soon to meet the same fate as the treaties and conventions which were concluded by England with our people at later periods. The violator of treaties fulfilled its obligation by decreeing in 1825 that all documents were for the future to be written in English. Petitions in the language of the country and complaints about bitter grievances were not even acknowledged. The Boers were excluded from the juries because their knowledge of English was too faulty, and their causes and actions had to be determined by Englishmen, with whom they had nothing in common."

99 They all remained at the Cape and continued practising. Although some (eg, Truter) appear if not to have accepted then at least not to have opposed anglicisation, others did raise their displeasure. Neethling, eg, was the only member of the replaced Court of Justice to protest in writing against the compulsory pensioning off of its members and he returned to practise as an advocate before the new Supreme Court: see n 67 supra. Some even openly fought for the Dutch cause. For instance, CJ Brand was one of a group of Afrikaner patriots, including lawyers Neethling and JA de Wet, involved with De Zuid-Afrikaan in 1830 and later became its editor. He was strongly opposed to the progressive anglicisation and its influence on the Dutch language in the 1820s and clashed with Wylde CJ in 1828 about the requirement that an understanding of English was a requirement for jury service.

100 Exile may already then have been in the Reitz family blood. After the English War, FW Reitz, like his uncle before him, preferred exile to swearing allegiance to Britain. He tried emigrating to Texas (where he had gone on a lecture tour) and also investigated settling in Europe and Madagascar; his son, Deneys Reitz, went into exile, mainly on Madagascar, for a period of three years after that war. Their bitterness after the war is readily apparent from FW's piece "Is it peace?" that appeared in (Nov 1902) 175 no 552 The North American Review 607-612. See, also, Moll 1977. 
course, Reitz was not the first lawyer to exchange the "Tavern of the Seas" 101 for the "Queen City of the East". ${ }^{102}$

\section{$7 \quad$ Batavia: Background}

With shared imperial links to the Dutch fatherland, there was a long history of the movement of not only goods but also people to and from Cape Town and Batavia. ${ }^{103}$ Batavia $^{104}$ was the capital city ${ }^{105}$ and main port and cultural centre of the Dutch East Indies. Located on the north-west coast of the island of Java, ${ }^{106}$ it was the eastern headquarters of the Dutch East India Company's administrative and commercial operations in the far east. ${ }^{107}$ In 1800, the former Company-controlled territories were

101 A description frequently taken over in book titles: see, eg, PW Laidler A Tavern of the Seas (1926, Cape Town); Lawrence Green Cape Town: Tavern of the Seas (1984, Cape Town).

102 See, eg, GG van der Kop Batavia: Queen City of the East (1925, Batavia). But then names can be misleading. Batavia was in fact, especially later in the nineteenth century, a rather unsavoury settlement, with stagnant and smelly canals, and a tropical Europeans' graveyard: see Blussé 1985; Pols 2011; Van der Brug 1997. Further, when Reitz arrived, the Dutch colony, although still wealthy, was nevertheless already in steady economic decline: see Adams 1996.

103 Not only the transfer of Company officials, but also emigration and "forced migration" in the form of slave trading, political exile and penal banishment (see, further, Ward 2009), meant that the residents of one city were not only aware of but also familiar with their counterparts in the other. Returning travellers to and from the East of necessity touched at the Cape, while even after the return of the British, many Dutch ships replenished here en route to and from the Dutch East Indies.

104 "Batavia" was also the ancient Latin name for the region - today part of the Netherlands inhabited by the Germanic Batavian people during the Roman Empire and from whence not only the name of the Dutch East Indian town (there is also a Batavia in Suriname in the West Indies) but also that of the Batavian Republic from 1795 to 1806. So, Simon van Leeuwen's Batavia Illustrata, ofte Verhandelingen vanden Oorsprong, Voortgang, Zeden, Eere, Staat en Godtsdienst van oud Batavien ... did not concern the Dutch East Indies. And then, of course, Leiden was formerly known as Lugduni Batavorum.

105 Other cities on the island of Java include Bantam (also on the north-west coast, west of Batavia; now Banten), Samarang (on the north coast, west of Batavia; now Semarang), Soerabaija (on the north-east coast; now Surabaya), and Banjoewangi (on the north-east coast; now Banyuwangi).

106 Other islands in the Dutch East Indies include the island of Sumatra (north-west of Java, with its main towns of Padang and Pelambang), and the islands of Borneo (north-east of Java), Bali (east of Java), Timor, Ambon, Celebes, Lombok, Ternate, and Tidore. For a description of the journeys undertaken by two visiting clerics ("kerkvisitators") at the time when Reitz arrived there, and from which some sense of the geography of (and the state of conversions to Christianity in) the mainly outlying parts of the empire, including the activities of slave traders and head-hunters ("koppensnellers"), may be gained, see Knappert 1927.

107 Previously called Jayakarta or Jaccatra, the Dutch had in 1609 established a fort at Batavia: Kasteel Batavia, which was demolished between 1808 and 1811. From 1619 it was the seat of the governor-general of the East Indies and it remained the entrepôt of the Dutch eastern trade until the end of the eighteenth century. Today it is (again) called Jakarta and it and the island of Java form part of Indonesia. On the background to the Dutch colonial administration of the East Indies, see, eg, Niemeijer 2007. 
nationalised and came under the administration of the Dutch government. In 1819, after the British interregnum (1811-1816) had ended and the piecemeal return of her former eastern territories to the Netherlands in terms of the London Convention of 1814, Batavia became the colonial capital of the Dutch empire in the east. In 1825, shortly after Reitz's arrival, the city had a population of some 40000 inhabitants: around 3000 Europeans, 30000 natives, 17000 Chinese, 1000 Arabs, and 5000 slaves. ${ }^{108}$ Less than a hundred Dutch-born and educated officials administered the colony ${ }^{109}$ under a governor-general. The governor-general ${ }^{110}$ of the East Indies governed in conjunction with the advisory Council of (Dutch) India and exercised executive and legislative power from Batavia.

As far as the law applicable in the East Indies was concerned, ${ }^{111}$ Dutch law, including its customs, was, in principle, the subsidiary common law applicable in the East Indian colonies until 1848. The principle of concordance applied in the Dutch East Indies: colonial law had to concur as much as possible with that in the Netherlands. In addition, a local compilation known as the (old) Statutes of Batavia of 1642, later replaced by the New Statutes of Batavia of 1766, provided supplementary regulation by rendering certain Dutch statutes applicable locally. Further, traditional Indonesian law and customs or adat, only recognised in 1766, governed the legal position of the indigenous, non-Christian population.

In 1848, the existing laws (both Roman-Dutch law and the Statutes) were largely supplanted with the introduction of a code - the Dutch East Indian Civil Code, Nederlands-Indisch Burgerlijk Wetboek - based on the new Dutch legal codes of 1838 on commercial, civil and procedural law, but with adaptations to suit local conditions. This was accompanied, as we will see shortly, by a general reorganisation of the colonial legal administration.

By the time of his arrival in Batavia, then, the default law applicable in practice was Roman-Dutch law, oud-Hollands recht, a system with which Reitz was more

108 See Van Dissel 2015: 46-47. See, further, Taylor 2009, with useful maps at 199-204; Kehoe 2015, with many illustrations and maps.

109 For a description of the colonial career and living conditions of a civil servant, Johan Pieter Cornets de Groot van Kraaijenburg (1808-1878), a lineal descendant of Hugo Grotius, in Java from 1816 to 1840 , when he rose from second custom house clerk to the position of acting general secretary (to the governor-general), and again from 1848 to 1851, when he was a member of the Council of India there, see Reinsma 1966.

110 The first joint commissioners-general (as they were then called) appointed in Sep 1814, but only arriving in the East in Apr 1816 and only taking over from the British in Aug of that year, were Cornelis Theodorus Ekhout, Godert Alexander Gerard Philip van der Capellen, and Arnold Adrian Buyskes. The latter had an interesting Cape connection and will feature again in due course (see nn 132 and 136 infra). For a list of the governors-general from 1610 to 1811, the (British) lieutenant-governors of Java from 1811 to 1816, and the governors-general from 1816 to 1888, see Van der Kloot 1891: 286-287.

111 See, further, Visagie 1969: 24-36; Salverda 2009: passim; Lev 1985: 62, referring to the competing legal regimes as creating a "legal maze"; Gall 1996a. 
than familiar. And, as before, "Batavia was then the summit for a lawyer in the east". ${ }^{112}$

\section{Reitz at the Batavian bar}

Both advocates and attorneys practised in the East Indies, with an attorney ordinarily instructing an advocate who, according to Dutch law, had the sole right of appearance in the higher courts. Both professions were regulated in detail. ${ }^{113}$

Some notion of Dirk Reitz's ${ }^{114}$ early years in legal practice in Batavia may be gained from various reports and advertisements that appeared in local and some Dutch newspapers. ${ }^{115}$

Reitz was admitted to practice as an advocate in Batavia on 4 September $1824 .{ }^{116}$ In September and October of that year there appeared announcements, in Dutch and English, that the office of advocate Mr DG Reitz was in "Koestraat, Batavia". ${ }^{117}$ Shortly thereafter he moved his office to Molenvliet. ${ }^{118}$

112 De Smidt 1996: 176.

113 The instructions for attorneys were issued in 1625 and both professions were regulated from 1735 and also in the Statutes of Batavia and in the New Statutes of Batavia. The rules of conduct included: the provision of security against malpractice and the prohibition of bare-headed pleading, contingency fees, verbose pleadings, chasing clients, and taking on excessive work. See, further, Ball 1982: 26-27.

114 Dirk Gysbert Reitz should be distinguished from two other Dutch colonial personages. First there was Gysbert Christiaan Bosch Reitz (1792-1866), an Amsterdam shipowner (see, eg, 4 Jun 1849 Nieuwe Rotterdamsche courant for an advertisement of the imminent departure for Batavia of the "Snelzeilend Gekoperd Tweedeks Fregatschip" Prins Maurits, of which GC Bosch Reitz was the owner) and merchant on and landowner in Surinam: see, further, http://www.kloek-genealogie. nl/BoschReitzGen.htm (accessed Nov 2015-Jan 2016). Secondly there was Carel Jan Riesz (not Reitz), a general in the military in Soerabaija in 1837: see Vreede-De Stuers 1996: 86 and 105; there is a reference to a former resident of Samarang, general-major CJ Riesz in Groot 2009: 310; see, also, 19 Sep 1835 Javasche courant where he is mentioned as the "Generaal Majoor, waarnemend Resident van Sourabaija".

115 The local newspapers consulted were the official Bataviasche courant (1816-1828), which became the Javasche courant (1828-1849); and the Bataviaasch advertentieblad, which became the JavaBode; Nieuws, handels- en advertentieblad voor Nederlandsch-Indie (1852-1897). For a list of Indonesian colonial newspapers, see https://www.kb.nl/organisatie, and for digital versions of the newspapers consulted and referred to here, see http://www.delpher.nl (both sites accessed during Mar 2016). The Dutch newspapers consulted were the official Nederlandsche staats-courant, the Leydse courant, the Opregte Haarlemsche courant, the Rotterdamsche courant, the Algemeen handelsblad, and the Nieuwe Rotterdamsche courant.

116 In the 7 Jan 1825 Leydse courant it was reported that on that date the governor-general in Batavia had appointed Reitz as advocate before the High Court and the Council of Justice there.

117 See 18 and 25 Sep and 2 Oct 1824 Bataviasche courant.

118 See 9 and 16 Mar 1825 Bataviasche courant. 
Notices also began appearing in connection with Reitz's acting as the executor of deceased estates ${ }^{119}$ or of insolvent estates, ${ }^{120}$ or as the representative of absent persons, ${ }^{121}$ or in judicial sales on behalf of the Batavian College of Orphan Masters ${ }^{122}$ or the local Vendue Office ${ }^{123}$ and others. ${ }^{124}$ Occasionally, something more interesting came his way. ${ }^{125}$

In December 1827 he gave notice of his intention to leave the island of Java for an undetermined time, appointing a representative to act for him while he was away, ${ }^{126}$ but by the end of April 1828 he was back in practice, sharing offices with another lawyer. ${ }^{127}$ By September 1829 he had moved offices to "buiten Nieuwpoortstraat" in the district of Kramat in Batavia, ${ }^{128}$ and by October 1830 he had moved offices again, to "binnen Nieuwpoortstraat", and gave notice of that and of his office hours. ${ }^{129}$

Reitz quickly became part of the local European community, acquiring membership of the Batavian Society of Arts and Sciences and other civic organisations. ${ }^{130}$

119 See 4 Dec 1824 Bataviasche courant (Tweede bijvoegsel) for an advertisement, dated 25 Nov 1824 by JN Olijve and DG Reitz that those who had claims against or debts owing to the deceased estate of one WA van der Hart (could he have been the captain of the Dageraad which had brought Reitz to Batavia a little more than two years before?: see at n 84 supra), were to give notice of it or make payment of it to them within six weeks. See also, eg, 9 Mar 1825 Bataviasche courant, in connection with the estate of W Spangenberg.

120 See 13 Dec 1825 and 21 Mar 1826 Bataviasche courant, announcing that advocate Reitz was administering the estates of certain insolvent persons on the instructions of the Council of Justice at Batavia after an application to the local Estates Chamber. See also, eg, $21 \mathrm{Mar}, 3$ and $26 \mathrm{Apr}, 17$ Jul, 13 and 15 Sep 1827 Bataviasche courant concerning his administration of insolvent estates.

121 See 6 Jul 1825 Bataviasche courant for an announcement that PA Heeger, departing to Benkoelen, had appointed Reitz and another person as his representatives ("gemagtigden").

122 See 17 and $28 \mathrm{Jul} 1827$ Bataviasche courant, advertising the judicial sale of goods on behalf of advocate Reitz as authorised representative of the College.

123 See 27 Oct and 1 Nov 1831 Javasche courant.

124 See 22 Mar 1830 Javasche courant, advertising the judicial sale of goods on behalf of advocate Reitz, "voor en van wegen de heeren Robert Wise \& Co". See also, eg, the advertisements in 25 Jan, 26 Mar and 20 Dec 1831 Javasche courant for his involvement in other judicial sales and auctions.

125 See 29 Mar and 3 Nov 1831 Javasche courant for his involvement in tontine claims.

126 See 6 and 8 Dec 1827 Bataviasche courant, notifying his intention to "verlaat voor eenigen tijd" the island of Java and his appointment of HJ Meijnderts as his authorised representative.

127 See 1 and 3 May 1828 Javasche courant, notifying that Reitz, himself "weder in de praktijk begevende", would retain his office at the premises of attorney Van Gent, next to that of notary K Heijnis. I could not establish whether Reitz visited the Cape during this period of absence from Batavia.

128 See 26 and 29 Sep 1829 Javasche courant.

129 See 28 and 30 Oct 1830 Javasche courant for a notice, in Dutch and English, that advocate Reitz had moved his office to the corner of "binnen Nieuwpoortstraat", where he could be consulted every day of the week from 9 am to 2 pm, except Wednesdays and Thursdays, and on those days from $11 \mathrm{am}$ to $2 \mathrm{pm}$ ( $1 \mathrm{pm}$ in the English advertisement!), and that every Friday morning from 10 am to $1 \mathrm{pm}$ he would devote his time to the settlement of accounts and the receipt and payment of monies.

130 See(1825) 10 Verhandelingen van het Bataviaansche Genootschap van Kunsten en Wetenschappen at lxxi, where Reitz, "Advokaat te Batavia”, is mentioned as one of its members; see, also, (1826) 11 Verhandelingen van het Bataviaansche Genootschap van Kunsten en Wetenschappen at xxxx. 


\section{Reitz and Gerrit Buyskes}

In September 1829 there appeared a most interesting advertisement, giving a brief and tantalising hint of Reitz's relationship with another expatriate Cape advocate. The advertisement ${ }^{131}$ invited parents and guardians desiring to let their children and pupils take lessons in drawing, to the house of "mr G Buijskes, op Kramat, dan wel ten kantore van den advokaat Dirk Gysbert Reitz in de buiten Nieuwpoortstraat".

Gerrit Buyskes (Buijskes) (1765-1832) ${ }^{132}$ was the secretary of the Cape Court of Justice from 1803 to $1806^{133}$ and a member of the Cape bar from 1806 to 1818 ; he had therefore left before Reitz joined. He was also admitted as a notary in $1806 .{ }^{134}$ The reason why Buyskes went to Batavia ${ }^{135}$ is not difficult to find. His brother, admiral Arnold Adriaan Buyskes (1771-1738), was one of the joint commissioners-general sent to Batavia in $1816 .{ }^{136}$ Gerrit arrived there in 1819 and was appointed a first-class

He remained a life-long member of this organisation: see Buddingh 1850: Appendix. The 13 Sep 1828 Javasche courant lists Reitz as one of the members of the Waterloo Society who had made a voluntary contribution to the erection of a monument.

131 See 26 and again 29 Sep 1829 Javasche courant.

132 Buyskes was born in Enkhuizen in the Netherlands on 2 Nov 1765, the eldest son of Pieter Buyskes (1739-1779), the mayor of the town. He graduated at Harderwijk in 1785, and occupied various minor offices until he went in exile to Flanders in 1789 . He was then active as a merchant in Bergen until 1791 and returned to Holland in 1795. After pursuing a brief political career, he practised as an advocate and notary in Amsterdam. In 1802 he was nominated as the secretary ("griffier") of the Court of Justice at the Cape and emigrated there. He resigned in 1806, when he was admitted and practised as an advocate at the local bar. He left the Cape for Batavia in 1819. His son Egbert Andries (1789-1865), one of eight children, remained behind in Cape Town where he practised as a notary and became joint vendue commissioner (see at $\mathrm{n} 11$ supra). See, further, on Buyskes and his family, Nieuw Nederlandsch biografisch woordenboek vol 1 available at $h t t p: / / w w w . d b n l . o r g$ (accessed 16 Mar 2016) sv "Buyskes, Arnold Adrian" at 527-529; Van der Aa 1854: $s v$ "Buyskes, Gerrit" at 1673-1674. For his will, see CA, MOOC 7/1/64 item 45 (1806).

133 See CA, CO 3857/263/1 (1806) for a memorial received from G Buyskes with an application to be relieved from his position as secretary of the Court.

134 See the Inventory of the Notarial Archives of the CoGH, 1790-1879, inventory no 1/7/1 item L. See, further, CA, CO 3891/722/1 (1812) for a memorial received from Buyskes concerning his practice as advocate and notary; CA, CO 3895/301/1 (1813) for a memorial from him with a request for permission to act as notary with the liberty to practice as an advocate; and CA, CO 3902/12/1 (1815) for a memorial from him resigning as notary. As noted, his son, Egbert Andries Buyskes, was also a notary: see the Inventory of the Notarial Archives of the CoGH, 1790-1879, inventory no 1/7/1 item AY; CA, CO 3891/723/1 (1812) and CA, CO 3902/28/1 (1815) for memorials received from Egbert Andries requesting to be permitted to practice as notary; and CA, CO 3908/214/1 (1817) for a memorial received from him requesting citizenship of the colony.

135 See CA, CO 3897/49/1 (1814) for a memorial received from Buyskes requesting that one of his sons be permitted to go to Batavia; CA, CO 3904/84/1 (1816) for a memorial from him requesting permission to depart for Batavia himself; and CA, CO 3917/156/1 (1820) for a memorial received from him requesting to take a Negro to Batavia.

136 See n 110 supra. Arnold Adria(a)n was a naval officer, served in the East Indies from 1789 to 1793 and again from 1803 to 1804 , was promoted to admiral and placed in charge of Dutch naval forces in the East Indies in 1807, and became vice-president of the Council of (Dutch) India in 1808. In 1814, he was appointed joint commissioner-general of the Dutch East Indies where he arrived in 1816. He served as such from Aug 1816 to Jan 1819, after which one of the other joint commissioners-general, Van Capellen, became (sole) governor-general until Jan 1826. His 
official of the East India Company and served as vice-president of the Supreme Court from 1820 to 1826 and again from 1828 to $1832 .{ }^{137} \mathrm{He}$ died in Batavia in April 1832.

Apart from the fact that both had immigrated from the Cape and that both had, albeit at different times, practised at the bar there, Reitz and Buyskes may have had more in common than merely a Cape background and their legal careers; there is a distinct possibility that they may have shared a love of the arts. ${ }^{138}$

\section{Reitz's judicial career}

At the time when Reitz practiced as advocate in Batavia, there were several courts of justice in the Dutch East Indies. ${ }^{139}$ They were located in the main centres on Java, such as in Samarang, Soerabaija, and Batavia, and also elsewhere in colonial territories in the East. They exercised criminal and civil jurisdiction over local Europeans - a separate system of courts existed for the indigenous population - and also an appellate jurisdiction over cases heard in the local lower courts, including the local College of Aldermen ("Schepenbank").

The Court of Justice in Batavia, already established in 1620 and comprised of a president and eight (later nine) members, additionally had appellate jurisdiction over cases heard in the other, outlying courts of justice, including the Court of Justice at the Cape. Like their Cape equivalent, the courts of justice were, until the late seventeenth century, generally not comprised of trained lawyers. Gradually, though, professional lawyers with Dutch law degrees came to be appointed as members and a greater but by no means complete independence of the Court from the High Government resulted.

In 1809, the Court of Justice in Batavia was abolished and replaced by the High Court of Justice ("Hooggerechtshof"). It was the highest judicial body in the East Indian colonies and in addition to its original jurisdiction, and an exclusive jurisdiction in some matters (for instance, piracy, crimes committed in places where no court had been established, or on board ships bound there), it retained its appellate jurisdiction, hearing not only appeals from and reviews of decisions by lower local

son Pieter (1794-1863) was a Leiden graduate in 1818, practised as an advocate in The Hague and Haarlem, and assumed judicial office in 1826, eventually becoming vice-president of the provincial Court of South Holland in 1849. His grandson Arnold Adriaan (1837-1915) likewise obtained a Leiden doctorate in 1861 with a thesis - aptly relevant to our man Reitz - entitled De Weeskamer en het collegie van boedelmeesteren te Batavia; he followed a colonial career in Batavia. See, further, Van der Aa 1854: $s v$ "Buyskes, Arnold Adrian" at 1674-1676.

137 See Briët 2015: 59, 105-106, 214, 242, 326. On his death, the office of vice-president of the Court was not filled again until 1839.

138 I came across a reference in Diehl 1990: 285 and 440 who mentions DG Reitz as a "music-master" and "musician", but, apart from his membership of the local society of arts and sciences (see n 130 supra) could find no further information on this aspect of Reitz's life (but see, also, n 191 infra).

139 On the court structures in the Dutch East Indies, see La Bree (nd); Toe Water 1882; Immink 1882; Stapel 1932; Ball 1982; and, in particular, Briët 2015. 
courts, but also from and by courts established elsewhere. There was no further appeal to any court in the Netherlands.

Further reforms were effected in 1819. The High Court of Justice in Batavia was replaced by the High Court of Justice of Dutch India ("Hoog Geregtshof van Nederlands-Indië'). It was regulated more closely ${ }^{140}$ by instructions issued in 1819 which were renewed in 1827,1830 , and 1836. It continued exercising both instance and also, as highest court in the East Indies, appellate, review and oversight jurisdiction, both now more precisely circumscribed. It, or rather its president, also gave legal opinions to the colonial government. ${ }^{141}$ The president ${ }^{142}$ and its quorum of eight members ("Raden") ${ }^{143}$ - reduced to five in $1827^{144}$ - had to be Dutch, older than twenty-five years of age, and graduates in law. Although the members were still appointed by the governor-general, from 1827 the Court's president (as also the procurator-general) were appointed by the Crown. Otherwise than in the Netherlands where judges were appointed for life, colonial judges were appointed for an undetermined period and could be removed, transferred or suspended by the governor-general or the Crown. Unlike members of the courts of justice, judges of the High Court could not hold any other offices.

In July 1833, the governor-general of the Dutch East Indies appointed advocate Dirk Reitz as a member of the Court of Justice at Samarang, a town west of Batavia on the island of Java. ${ }^{145} \mathrm{~A}$ few months later, in April 1834, he was made a member of the Court of Justice in Batavia. ${ }^{146}$ In September 1835, he was appointed as fiscal at the Court of Justice in Soerabaija, another town on the island of Java. ${ }^{147}$

140 As were the outlying courts of justice.

141 For instance, on matters pertaining to the administration of justice, legal matters (including, eg, questions of prize) and new legislation: see Briët 2015: 237-246. It also performed special tasks such as announcing legislation, controlling seals ("stempeling van kleinzegel"), and executing and passing deeds.

142 See idem at 246-259, 326. The highest ranking member acted in his place when the president was absent. Unofficially there was a vice-president (in reality, merely an ordinary member with that title) only intermittently. Gerrit Buyskes served in that capacity (see n 137 supra), but the office disappeared with his death in 1832 and only returned in 1839 in order to lighten the workload of the president: see idem at 214-216.

143 In addition to ordinary members, extraordinary and acting members were also appointed to the Court as circumstances demanded: see idem at 216-217.

144 See idem at 217-219, 259-269.

145 See 27 Jul 1833 Javasche courant; see, also, 26 Dec 1833 Rotterdamsche courant and 31 Dec 1833 Nederlandsche staats-courant.

146 See 26 Apr 1834 Javasche courant. Later in the year he was assigned specified functions (eg, the "folieren en parapheren" of official documents) in the Court for the year 1835: see 27 Sep 1834 Javasche courant. A year later the assignment was repeated with another member being appointed alongside him to fulfil those official functions on behalf of the Court: see 16 Sep 1835 Javasche courant.

147 See 9 Sep 1835 Javasche courant; see, also, 4 Jan 1836 Nederlandsche staats-courant and 4 Jan 1836 Algemeen handelsblad. 
Then, after all that, ${ }^{148}$ in March 1836 the governor-general appointed Reitz ${ }^{149}$ as one of the five members of the High Court ("Raadsheer van den Hoog Gerechtshof"), seated in Batavia. ${ }^{150}$

Reitz occupied this position for eleven years, until $1847 .{ }^{151}$ During the period of the Court's existence, from 1819 to 1848, the High Court had, apart from five presidents, ${ }^{152}$ a total of thirty-two members who officiated as judges. ${ }^{153}$ Some had been presidents or members of one of the courts of justice on Java or elsewhere in the East Indies, some fiscals, while others had been sent out from the Netherlands. ${ }^{154}$ Dirk Gysbert Reitz was the twenty-seventh appointee. ${ }^{155}$

In September 1837, the five ordinary members of the High Court - JA Verploegh, LH du Bus, C Visscher, C Hultman, and DG Reitz - sent a memorial to the governor-general in which they complained about their salaries. ${ }^{156}$ They pointed out that with the Court's president being sent out from the Netherlands rather than being appointed from its incumbent members, their only avenue of promotion and an increase in remuneration was to be appointed as its (better salaried) procurator-

148 These various appointments naturally necessitated translocation and no doubt caused great inconvenience to Reitz and his family. The Javasche courant of 7 Oct 1835 announced the arrival at Samarang on 30 Sep of Reitz and his family with the Dutch brig Harriet, and their departure for Soerabaija on 1 Oct; they arrived there on 7 Oct: see 14 Oct 1835 Javasche courant. On 25 May 1836, the same paper announced the departure of Reitz and his family on 14 May with the Dutch ship Dortenaar from Soerabaija to Batavia and his arrival there on 22 May. On $12 \mathrm{Apr}$ 1837 , the Javasche courant published an announcement of the public sale of goods scheduled for the following month, including a "zeker huis en erve, staande en gelegen op Rijswijk, verhuurd tot $f 160$ zilvergeld per maand en bewoond door den heer DG Reitz".

149 See 30 Mar 1836 Javasche courant; see, also, 16 Aug 1836 Rotterdamsche courant and 17 Aug 1836 Leydse courant. He was appointed as the replacement of BG Rinia van Nauta who had been appointed as circuit-court judge ("ommegaand regter") in Samarang.

150 Initially located in the Town Hall ("Stadhuis") in Batavia, in 1828 the Court moved to the Daendels Palace on Waterlooplein, in the Batavian district of Weltevreden. From 1848 it was housed in its own new building next to the Palace on the same square.

151 His name is listed as member of the High Court in the various editions of the annual Jaarboekje van de Regterlijke Magt in het Koningrijk der Nederlanden. See, also, the Almanak en naamregister van Nederlandsch-Indie voor 1847 (Batavia, 1847) at 9.

152 The presidents were: Pieter Simon Maurisse, president (1819-1828), a Company official and president of the former Batavian High Court of Justice (1807-1809) and fiscal (1803-1807); Pieter Merkus, president (1828-1829), formerly the procurator-general in 1819 and later a member of the Council of India and eventually the governor-general; Georg Cornelis Hageman, president (18311837); Christian Jacobus Scholten van Oud Haarlem, president (1837-1845); and Hendrik Ludolf Wichers, president (1846-1849). The last three were lawyers specially sent from the Netherlands to fill the office as there were no suitable locals. See, further, Briët 2015: 246-259, 326.

153 Seven of them were extraordinary or acting members, the rest were ordinary, appointed and thus sworn in.

154 See, further, Briët 2015: 259-269.

155 Idem at 327.

156 For this, see idem at 226-233. 
general. ${ }^{157}$ Their salaries were much lower than that of many other officials, some of whom were subject to the authority of the Court. ${ }^{158}$ The Council of India agreed and, stressing the importance of continuity on the bench, advised the governor-general to recommend to the government in the Netherlands that an improvement in their salary structure was necessary. The president of the Court, Christian Jacobus Scholten van Oud Haarlem, also supported their memorial. Although the governor-general recommended improved salaries for the members of the High Court, the ultimate response from the Netherlands, in December 1838, was negative, unfavourable economic conditions being proffered as the reason.

In January 1839 Reitz was additionally appointed as a member of the Military High Court ("Hoog Militair Geregtshof"). ${ }^{159}$ It exercised jurisdiction over members of the military and naval forces in the East Indies. ${ }^{160}$ The president of the civilian High Court was also the president of the Military High Court and two members of the High Court were appointed also to serve on this tribunal. ${ }^{161}$

In 1848, with the introduction of a new civil law in the Dutch East Indies, the court structure too was reorganised. Although most serving members of the retained High Court were reappointed, ${ }^{162}$ Reitz no longer held judicial office, his appointments having come to an end the year before. However, he continued in public office in Batavia.

157 The procurators-general during Reitz's time were: Pieter Merkus (1819-1821); Pieter Hendrik Esser (1821-1825), who became a member of the Court in 1821; Gerard Theodoor Blom (18251828), after he had been a member from 1819 to 1822; Joan Hendrik Spiering (1828-1838), who had been a member from 1822 to 1825 and again in 1838; and Carl Hultman (1838-1848), who had been a member in 1835 and 1836. See, further, Briët 2015: 269-282, 327.

158 For instance, the resident on Java (in the Company era, a resident was an official below the rank of commander, director and governor, but above that of factory head) at the time earned a monthly income of $f 1250$, apart from additional fringe benefits, while a member of the High Court earned only $f 1000$ per month. Members' salaries were also lower than those of a fiscal with one of the courts of justice. See idem at 226-233.

159 See 2 Jan 1839 Javasche courant; see, also, 25 May 1839 Rotterdamsche courant, 25 May 1839 Opregte Haarlemsche courant. He was appointed in the place of JA Verploegh, who departed on leave to the Netherlands. Reitz was therefore referred to as a member of both Dutch Indian courts ("Raad in de beide Geregtshoven van Nederlandsch Indië"): see, eg, (1842) 18 Verhandelingen van het Bataviaansche Genootschap van Kunsten en Wetenschappen at 42. Possibly this court was mistaken for a maritime or Admiralty court: see at $\mathrm{n} 1$ supra.

160 The Jaarboekje van de regterlijke magt in het koningrijk der Nederlanden voor 1846 (Gorinchem, 1846) at 234-235 described its jurisdiction as being over "alle Militairen en andere tot de Koloniale Land- en Zeemagt behoorende personen" in so far as their wrongs did not concern "'s lands lasten en middelen".

161 Apart from the High Court's president and two of its members, its registrar and procurator-general likewise served in the Military Court and these were the only legally qualified members on it; none of them received any additional remuneration. See, further, Briët 2015: 216, 236-237.

162 Idem 308-314. 


\section{President of the Batavian Orphan Chamber}

In the course of 1847, Dirk Reitz was appointed as president of the Orphan Chamber in Batavia, ${ }^{163}$ an office he occupied until his death sixteen years later. ${ }^{164}$

Orphan chambers ("weeskamers") ${ }^{165}$ existed in many Dutch towns, also in the colonies. There were such chambers in Batavia ${ }^{166}$ and also in Samarang and Soerabaija and elsewhere in the East Indies, as also in Cape Town. ${ }^{167}$ The main functions of these chambers were to administer the legacies and other capital and property of orphans and to act as curators on behalf of minors where one or both of their parents had died (so-called full or half orphans ${ }^{168}$ ) for the protection of their financial, material, physical, and educational interests until they themselves got married or reached majority. They also performed several minor, ancillary functions. ${ }^{169}$

The Orphan Chamber in Batavia had been established in 1624. In addition, and established subsequently in the course of the seventeenth century, there were in Batavia, as in many locations elsewhere, two other comparable subsidiary bodies: an Estate Chamber ("Boedelkamer") which administered the estates of persons who had died without heirs or whose heirs were absent, or who had died intestate, ${ }^{170}$ as well

163 See 27 Mar 1847 Nederlandsche staats-courant and the Almanak en naamregister van Nederlandsch-Indie voor 1847 (Batavia, 1847) mentioning at 395 Reitz's appointment as one of changes that had occurred (after printing) up to 15 Feb 1847.

$164 \mathrm{He}$ is mentioned as holding that office in the various annual editions of the Almanak en naamregister van Nederlandsch-Indie; see, also, eg, Nederlandsche residentie- en 's Gravenhaagsche stadsalmanak voor 1850 (The Hague, 1850) at 350.

165 An orphan chamber or chamber of wards is also referred to as an orphan board ("college van weesmeesters" or "weesheren").

166 On the Orphan Chamber in Batavia, see the doctoral thesis of Arnold Adriaan Buyskes (who was the son of the governor-general and the nephew of Gerrit: see n 136 supra) Weeskamer en collegie van boedelmeesteren te Batavia (Leiden, 1861) and also the doctoral thesis of Pieter Paulus De collegiis pupillaribus (Weeskamers) ... (Leiden, 1832); Gall 1996b. For the Chamber's archive, see Kortlang 2007.

167 On the Cape Orphan Chamber, see, eg, Botha 1962: 113-135; Visagie 1969: 56-60 and 110-111; and Ehlers 2000: 178-179. The Cape body was established in 1673, consisting of five elected members: two Company officials (one of whom was president) and three burghers. Membership increased to six from 1699, with the addition of a vice-president. From 1803 to 1806, the posts of president and vice-president were filled permanently. An Estate Chamber was established at the Cape in 1803. During the British period from 1806 to 1828, the president of the Court of Justice also acted as the president of these chambers. They were abolished by Ordinance 104 of 1833 and their functions transferred to the Supreme Court. Litigation involving the Orphan Chamber continued right up to its abolition: see, eg, Orphan Chamber $v$ Sertyn \& Others (1831) 1 Menzies 25; Loedolff $v$ The Present Orphan Chamber and the Surviving Members of the Former Orphan Chamber (1830) 1 Menzies 486; In re Durr. Orphan Chamber qq Minor Heirs in re Durr v Van Reenen (1832) 1 Menzies 565.

168 The protection of a half orphan was especially called for if the surviving parent remarried.

169 For instance, the registration of the wills of deceased persons; and keeping a death register or record of persons who had died in its area of jurisdiction.

170 So-called "unclaimed estates" ("desolate boedels" or "onbeheerde nalatenschappen"). Instances of absent heirs occurred frequently in the colonial setting. 
as insolvent estates; and an Estate Chamber for Non-Christian (or non-European) Foreigners. ${ }^{171}$ Although these different chambers were in most East Indian locations joined and regulated together at the beginning of the nineteenth century, the Batavian Orphan Chamber and the Estate Chamber continued to operate separately and were only merged in 1885 .

Orphan chambers were also important in another respect. As their administration of legacies and the liquidation of property gave them control over the accumulated capital involved, they were important financial institutions and providers of credit at a time when banks were few and far between. A large part of their business involved making (government guaranteed) loans of money to local merchants and businesses at interest and on security in the form of bonds over immovable property. Although by the end of the seventeenth century, it had become common to exclude these chambers from any management of the capital bequeathed in a will, ${ }^{172}$ they retained their importance as guarantors of the fact that testamentary depositions and legacies would be settled. Naturally, they retained their importance for the welfare of minor orphans.

The Batavian Orphan Chamber was further significant in that it supervised and received regular reports from like chambers established elsewhere in the Dutch colonial empire and also exercised jurisdiction over legacies and estates in places where there was no local chamber.

Reitz's appointment as president of the Orphan Chamber in Batavia in 1847 was therefore a prestigious and influential one. ${ }^{173}$ Some indication of his stature in the East Indies is the fact that in 1844, when still on the High Court bench, the University of Utrecht conferred an honorary doctorate on him. ${ }^{174}$ In December 1851

171 "Onchristelijke Boedelkamer", "Boedelkamer voor Vreemde Oosterlinge", or "College van Boedelmeesters van Chinese en Andere Onchristen Sterfhuizen". This body was necessary as the Orphan Chamber and the Estate Chamber dealt only with the estates of Europeans.

172 For an English case involving the exclusion of the Batavian Orphan Chamber, see Phillips $v$ Thornton (1831) 3 Hagg Ecc 752, 162 ER 1332; see also, generally, Cockerell v Dickens (1840) 3 Moore 99, 13 ER 45 and (1840) 2 Moore Ind App 353, 18 ER 343.

173 Interestingly, he was not the first Cape-connected person to hold the presidency. Dutch-born Johannes Cornelis D'Ablaing (1663-1721), who had been second in command and then acting governor at the Cape (May 1707-Feb 1708, in the place of the recalled WA van der Stel, to whom he was related), was president of the Orphan Chamber in Batavia from 1718 to 1721: see Nederlands adelsboek 1906 (The Hague, 1906) at 2. Reitz further had an indirect connection to the Cape Chamber. For litigation involving it and also one of Reitz's relations on his mother's side, see [President and Members of the] Orphan Board v [Johannes Gysbertus] Van Reenen \& Bayley (1829) 1 Knapp 82, 12 ER 252, on appeal from the Cape where the Chamber was described (at 86-87, 254) as "a corporation, instituted at the Cape, as well as in most of the other Dutch colonies, for the purpose of administering the property of orphans".

174 See Digitaal album promotorum Universiteit Utrecht (accessed 14 Jan 2016) sv 'Reitz' where it is mentioned that Didericus Gysbertius Reitz, "supremae curiae in India Batavia senator", received an honorary doctorate on 23 Nov 1843. The 16 Oct 1844 Nederlandsche staats-courant (and also the 18 Oct 1844 Leydse courant) announced that a gathering of alumni ("oud-studentenfeest") of Dutch universities ("vaderlandsche Hoogescholen") was planned in Batavia on 2 Aug, an invitation to attend being extended to them by a committee of which Reitz was listed as a member. 
Reitz was created a Knight in the Order of the Netherlands Lion ("Ridder der Orde van den Nederlandschen Leeuw"), ${ }^{175}$ a Dutch order of chivalry founded in $1815 .{ }^{176}$

\section{The Reitz family in Batavia ${ }^{177}$}

Dirk Reitz spent his first few years in Batavia as a bachelor. On 22 September 1831, he married Miss Geertruida Leonora Liesart. ${ }^{178}$ Sadly the union did not last long as only four months later, on 22 January 1832, his newly-wed wife passed away. ${ }^{179}$

A little more than three years later, widower Reitz found love again. On 19 February 1835, the thirty-nine-year old Reitz married the twenty-two-year old Miss Louisa Johanna van de Poel. ${ }^{180}$ The couple had three children.

The eldest, Frederik Geerte Adolph, was born on 17 November 1840 in Batavia. ${ }^{181}$ Like his father he studied law in the Netherlands, at Leiden, graduating $\mathrm{M}$ Iuris in 1859. Returning to Batavia in 1877, he pursued an illustrious legal and, from 1882, judicial career in the East Indies, culminating in his holding the appointment

175 The royal announcement appeared in the Almanak en naam-register van Nederlandsch-Indie voor 1851 (Batavia, 1851) at 201 where Reitz's name appears as one of a large number of such knights. See, also, 6 Dec 1847 Nederlandsche staats-courant and 7 Dec 1847 Rotterdamsche courant.

$176 \mathrm{He}$ is not the only South African-born to be honoured in this way: Paul Kruger and Jan Smuts were subsequently created Knights Grand Cross - a higher rank, awarded only to members of the Dutch and foreign royal families and to foreign heads of state - in the same order.

177 For most of what follows, see http://www.genealogieonline.nl (consulted several times in Jan 2016).

178 See 24 and, also, 27 Sep 1831 Javasche courant.

179 See 24 and, also, 26 Jan 1832 Javasche courant, announcing the death of his "tedergeliefde echtgenoote" in Batavia.

180 See 25 and, also, 28 Feb 1835 Javasche courant. She was born 12 Sep 1812 in Batavia, and died Apr 1883 in The Hague (see (1883) 1 De Nederlandsche Leeuw 39-40 noting her death; see, also, South African Genealogies 2003: 250, which incorrectly gives the date of marriage as "c 1832"). The bride was a daughter from the second marriage of Pieter van de(r) Poel (1786-1833), a civil servant and governor of various regions in the Dutch East Indies. See, eg, (1860) 9 Tijdschrift voor Indische taal-, land- en volkenkunde (IIIe Serie) at 76, mentioning Van de Poel as "resident" of the "gewestelijk bestuur van Tagal" in 1833; Knight 2014: 121 n 228, mentioning Van de Poel as local governor ("resident") of Tegal from 1824 to 1833. She may have had a sister: see 6 and 17 Jul 1839 Javasche courant, referring to the departure from Batavia and arrival in Samarang with the Dutch steamer Van der Capellen of the passengers Mrs Reitz and "de jonge jufvrouw S van de Poel".

181 See 21 Nov 1840 Javasche courant, announcing the "voorspoedig bevallen van eenen zoon, LJ van de Poel, geliefde echtgenoot van mr DG Reitz", on 17 Nov. On Frederik, see http://www. MyHeritage.com (accessed 13 Jan 2016) sv "Frederik Reitz"; George 2011: 52. 
of president of the Court of Justice in Padang from 1897 to $1899 .{ }^{182}$ Also a legal author, ${ }^{183}$ Frederik Reitz returned to Europe and died in Paris in 1910.

The couple also had a second son and a daughter, both of whom died young ${ }^{184}$ and predeceased their father.

\section{The death of Dirk Reitz}

After more than thirty tears in the tropics, it should probably not come as a surprise that Dirk Reitz too succumbed to disease. In June 1853 he was granted six months' leave to go on a voyage to Japan because of illness, "en zulks met behoud van zijne betrekking". ${ }^{185}$ He departed from Batavia at the beginning of July on the Dutch merchantman Hendrika, ${ }^{186}$ bound for Japan, ${ }^{187}$ and in the company of some other local worthies. ${ }^{188}$

182 Some of his judicial appointments are announced in 15 Sep 1893 Java-bode, 15 Sep 1893 Bataviaasch nieuwsblad, 15 Sep 1893 De Locomotief: Samarangsch handels- en advertentieblad, and 19 Sep 1893 Soerabaiasch handelsblad (as vice-president of the Court of Justice in Semarang); 6 Aug 1898 De Locomotief: Samarangsch handels- en advertentie-blad (as "president van den raad van justitie te Padang"). There is clearly some confusion between father and son in many sources, including JCM 1972, who describes Dirk as having been Chief Justice of Padang.

183 Named as Fredericus Georgius Arnoldus Reitz, he was co-compilor, with Louis Antoine de Filliettaz-Bousquet, of a further edition of De Nederlandsch-Indische wetboeken, benewens de grondwet voor het koninkrijk der Nederlanden ..... zooals zij tot op 9 December 1881 zijn gewijzigd en aangevuld (The Hague, 1882).

184 The son was Bernardus Ferdinandus Franciscus, b Jan 1843, d 28 Mar 1846 (see 14 and, also, 18 Jan 1843 Javasche courant, announcing the "bevallen van eenen zoon, de geliefde echtgenoot van mr DG Reitz"); the daughter was Henrietta Laetitia, b Jan 1844, d Jan 1850 (see Almanak en naam-register van Nederlandsch-Indie voor 1851 (Batavia, 1851) at 425).

185 See 18 Jun 1853 Java-Bode; 15 Aug 1853 Algemeen handelsblad; 16 Aug 1853 Nederlandsche staats-courant.

186 An 860-ton wooden frigate with copper-sheathing, the Hendrika (as to which see http://www. scheepsindex.nl and http://www.marhisdata.nl (both accessed 8 Feb 2016)), was launched in 1836 in Rotterdam. Plying the Europe-Batavia route for many years (eg, in 1839 the then president of the High Court, Scholten (see n 152 supra), returned with her to the Netherlands on sick leave: see Briët 2015: 251-252), she had departed for Batavia from Hellevoetsluis on 23 Nov 1852 (see 29 Nov 1852 Utrechtsche Provinciale en Stads-courant), bound for the East Indies and under the command of Capt P Admiraal. Her voyage to Batavia and Japan turned out to be her last, for on 4 Dec 1854 she was lost with all eighty-two souls on board near De Banjaard, a sandbank off the coast of Zeeland.

187 The Dutch in the East Indies had been trading on - and clashing with - Japan and operating a factory or trading post there for many decades, from the beginning of the seventeenth century: see Clulow 2014; Boot 2015: 179-202.

188 On board were the "pakhuismeester, boekhouder ende scriba" of the Dutch trade mission in Japan, PJ Lange. Also on board were a civil servant R (or K) Graafland; a medical doctor, JK van den Broek; the "pachter van den Kambang handel", AJJ de Wolff; a pensioned official, JR Lange; and a member "der algemene rekenkamer", JH Vemer. The latter, and Reitz, were travelling "tot herstel hunner gezondheid". See 6 Jul 1853 Java-Bode; 30 Aug 1853 Algemeen handelsblad; 30 Sep 1853 Rotterdamsche courant; 2 Sep 1853 Leydse courant. 
On 7 July, a few days after leaving the Batavian roadstead and while nearing the Banda islands, ${ }^{189}$ Dirk Reitz passed away, virtually on the other side of the world from where he was born. ${ }^{190}$

Dirk Reitz must have anticipated and feared the worst, for soon after his departure, on 30 July 1853, the Java-Bode advertised the upcoming auction, on Monday 1 August, by Vaupel en Co, in front of the residence of the "weledelgestrengen" $\mathrm{Mr}$ Reitz, at Rijswijk, of "wagens, en dezelfs goed geconserveerden inboedel, alsmede een Pianino van Herce et Mainé, te Parijs, voor dit klimaat vervaardigd". ${ }^{191}$ Sadly, like so many other Europeans, and unlike his musical instrument, Reitz was not made for the local climate.

\section{ABSTRACT}

Dirk Gysbert Reitz was born in Cape Town in 1796 and died in the East Indies in 1853. An advocate at the Cape bar in the early 1820 s, he emigrated to Batavia where he pursued a successful legal and judicial career. Through his life, we are afforded a snapshot of the state of law and legal administration and practice in two RomanDutch jurisdictions, the one by then a British and the other still a Dutch colony.

\section{BIBLIOGRAPHY}

Adams, Julia (1996) "Principals and agents, colonialists and Company men: The decay of colonial control in the Dutch East Indies" American Sociological Review 61: 12-28

AEB (1968) "Brand, Christoffel" in Dictionary of South African Biography vol 1 (Cape Town): $77-78$

AFH (1968a) "Bannister, Saxe" in Dictionary of South African Biography vol 1 (Cape Town): 50

AFH (1968b) "Cloete, Hendrik (Henry)" in Dictionary of South African Biography vol 1 (Cape Town): 171-173

189 East of Java, the Banda islands (including Great Banda, Run and Neira), together with the Moluccas and Amboyna, form the Spice Islands. They were occupied by the Dutch in an infamous incident in 1621 after a prolonged Anglo-Dutch rivalry: see Van Ittersum 2016; for a popular account of the events leading up to the Dutch atrocities during their brutal and genocidal conquest of Banda, see Giles Milton's bestselling Nathaniel's Nutmeg: How One Man's Courage Changed the Course of History.

190 See 21 and, also, 24 Dec 1853 Java-Bode (notice by Louisa Reitz of the death "aan boord van de Hendrika, in bestemming naar Japan, van mijn geliefde echtgenoot mr DG Reitz, in leven President van de Weeskamer te Batavia"); see, also, 15 Feb 1854 Algemeen handelsblad; 17 Feb 1854 Leydse courant (from which it appears that news of his death only became known in Batavia on 15 Dec when the Hendrika returned from Japan). Louisa Reitz and her son, Frederik, returned to the Netherlands in 1855 (see 4 Jun 1855 Nieuwe Rotterdamshe courant: most coincidentally also on board, after an uninterrupted thirty-nine-year stay in the East Indies, was L Steitz, the pensioned former president of the Orphan Chamber at Batavia and predecessor of Reitz).

$191 C f$, again, n 138 supra. 


\section{JP VAN NIEKERK}

Ahsmann, Margreet (1993) Bibliografie van hoogleraren in de rechten aan de Utrechtse Universiteit tot 1811 [part 7-2 Geschiedenis der Nederlandsche rechtswetenschap] (New York, NY)

AL-S (1968) "Reitz, Deneys" in Dictionary of South African Biography vol 1 (Cape Town): 670

Anon (1903) “The Late Hon Petrus J Denyssen” SALJ 20: 221-223

Ball, John (1982) Indonesian Legal History 1602-1848 (Sydney)

BB (1968) “Truter, Johannes Andreas (Sir John)” in Dictionary of South African Biography vol 1 (Cape Town): 805-806

Beyers, Coenraad (1967) Die Kaapse Patriotte Gedurende die Laaste Kwart van die Agtiende Eeuw en die Voortlewing van hul Denkbeelde (Pretoria)

Bickford-Smith, Vivian (2003) "Revisiting anglicisation in the nineteenth-century Cape colony" $J$ of Imperial \& Commonwealth History 31: 82-95

Bird, WW (1823) State of the Cape in 1822 by a Civil Servant (London) [reprinted in 1966 as vol 19 Africana Collectanea Series (Cape Town)]

Blommaert, W \& Wiid, JA (eds) with an English translation by JLM Franken \& Ian M Murray (1937) Joernaal van Dirk Gysbert van Reenen 1803 [Van Riebeek Society Publications no 18] (Cape Town)

Blussé, Leonard (1985) "An insane administration and insanitary town: The Dutch East India Company and Batavia (1619-1799)" in Robert J Ross \& Gerard J Telkamp (eds) Colonial Cities. Essays on Urbanism in a Colonial Context (Dordrecht): 65-86

Boot, Wim (2015) “"Not out of love, but for money and profit': Dutch-Japanese trade from the seventeenth to the nineteenth century" in Catia Antunes \& Jos Gommans (eds) Exploring the Dutch Empire. Agents, Networks and Institutions, 1600-2000 (London): 179-202

Botha, C Graham (1918) "Sir John Andries Truter ... Chief Justice of the Cape of Good Hope" SALJ 35: 135-154

Botha, C Graham (1924) "Early legal practitioners of the Cape Colony" SALJ 41: 255-262

Botha, C Graham (1962) Collected Works III. Cape Archives and Records (Cape Town)

Brand, Ron (2010) "Deining, in de duinen. Maritieme prenten op Kasteel Keukenhof" in Gerard Jaspers (ed) Zeehelden, kooplieden, lords en ladies op kasteel Keukenhof [vol 4 Jaarboek Kasteel Keukenhof] (Hilversum): 11-30

Briët, Kees (2015) Het Hooggerechtshof van Nederlands-Indië 1819-1848. Portret van een vergeten rechtscollege (Amsterdam)

Buddingh, SA (1850) Verslag van den staat der werkzaamheden van het Bataviaasch Genootschap van Kunsten en Wetenschappen (Batavia)

Burrows, Edmund H (nd) Overberg Outspan. A Chronicle of People and Places in the South Western Districts of the Cape (Cape Town)

Burrows, EH (1959) “Lieutenant Johannes Jacobus Reitz, RN (1801-24)" Africana Notes \& News 13: $207-222$.

Burrows, Edmund H (1994) Overberg Odyssey. People, Roads and Early Days (Swellendam)

Cloete, JH de V (1934) "Mr Justice Cloete" SALJ 51: 1-10

Clulow, Adam (2014) The Company and the Shogun. The Dutch Encounter with Tokugawa Japan (New York, NY) 
Cowen, Denis (1959) "The history of the Faculty of Law in the University of Cape Town, 18591959: A chapter in the story of the survival and growth of Roman-Dutch law in South Africa" Acta Juridica: $1-19$

Crais, Clifton \& McClendon, Thomas V (eds) (2013) The South Africa Reader: History, Culture, Politics (Durham, NC)

De Smidt, JTh (1996) "Roman-Dutch authorities at the Cape in the eighteenth century" Fundamina. A J of Legal History 2: 175-181

De Vries, C (1786) Naauwkeurige beschryving en verhaal ... van de honderd vyftigste verjaring der Utrechtse Hoge Schole op ... 31 May 1786 .... (Utrecht)

Diehl, Katherine Smith (1990) Printers and Printing in the East Indies to 1850. Vol 1: Batavia 1600-1850 (New York, NY)

Digitaal album promotorum Universiteit Utrecht (accessed 14 Jan 2016), available at http://www. dap.library.uu.nl

Dooling, Wayne (2005) "The making of a colonial elite: Property, family and landed stability in the Cape Colony, c 1750-1834” J of Southern African Studies 31: 147-162

Dubow, Saul (2009) "How British was the British world? The case of South Africa" J of Imperial and Commonwealth History 37: 1-27

Ehlers, Anton (2000) "Die Anglo-Boereoorlog as stimulus vir die stigting van Afrikaanse plattelandse trustmaatskappye en eksekuteurskamers" Historia 45: 177-197

Ekker, A $(1863,1864)$ De Hieronymusschool te Utrecht Deel 1: 1474-1636 and Deel 2: 16361849 (Utrecht)

Erasmus, HJ (2015) "The beginning of a mixed legal system or, advocates at the Cape during the early nineteenth century, 1828-1850" Fundamina. A J of Legal History 21(2): 219-233

Farlam, IG (1988) "The origin of the Cape Bar" Consultus 1: 36-39

FGEN (1968) "Beelaerts van Blokland, Jonkheer Gerard" in Dictionary of South African Biography vol 1 (Cape Town): 44-46

FJuTS (1968) "Hiddingh, Cornelis" in Dictionary of South African Biography vol 1 (Cape Town): 298-299

Freund, William M (1989) “The Cape under the transitional governments, 1795-1814” in Richard Elphick \& Hermann Giliomee (eds) The Shaping of South African Society, 1652-1840 (Cape Town): $324-357$

Gall, Heleen (1996a) "An introduction to Indonesian legal history" Fundamina. A J of Legal History 2: 144-155

Gall, HC (1996b) "De weeskamer in Nederlands-Indië als negentiende-eeuws instituut" in CJH Jansen, E Poortinga \& TJ Veen (eds) Twaalfbijdragen tot de studie van de rechtsgeschiedenis van de negentiende eeuw (Amsterdam): 29-43

George, John (2011) The Genealogical Impact on South African History of the Prussian Settler Count Jacob van Rhenen Who Arrived in the Cape in 1721 (ebook, http://www.Lulu.com)

Gregg, Lyndall (18 Jan 1952) "Lieut Jacobus Johannes (James) Reitz of the British Navy" The Outspan: $55-57$

Groot, Hans (2009) Van Batavia naar Weltevreden. Het Bataviaasch Genootschap van Kunsten en Wetenschap, 1778-1867 [no 243 Verhandelingen van het Koninklijk Instituut voor Taal-, Land- en Volkenkunde] (Leiden) 
HAH (1968) "Faure, Abraham" in Dictionary of South African Biography vol 1 (Cape Town): 229-233

HBG (1972a) "Bresler, Frans Reinhard" in Dictionary of South African Biography vol 2 (Cape Town): 87-88

HBG (1972b) "Van Rijneveld, Willem Stephanus" in Dictionary of South African Biography vol 2 (Cape Town): 807-808

HCB (1968a) "Brand, Christoffel Joseph" in Dictionary of South African Biography vol 1 (Cape Town): 78-84

HCH (1968b) "Berrangé, Jan Christoffel” in Dictionary of South African Biography vol 1 (Cape Town): 54-55

HCH (1972) "Borcherds, Petrus Borchardus" in Dictionary of South African Biography vol 2 (Cape Town): 69-70

Heese, JA (1981a) “Truter, Hendrik Andreas (Andries)" in Dictionary of South African Biography vol 4 (Pretoria): 662

Heese, JA (1981b) "Van der Poel, Cornelis" in Dictionary of South African Biography vol 4 (Pretoria): 689-690

Hoge, J (1960) “Some notes on Jan Frederik Reitz” Africana Notes \& News 14: 76-77

Immink, A (1882) Regterlijke organisatie van Nederlandsch Indië (Amsterdam)

JCM (1972) "Reitz, Francis William" in Dictionary of South African Biography vol 2 (Cape Town): $575-577$

JCV (1968) "Hiddingh,Willem" in Dictionary of South African Biography vol 1 (Cape Town): 299-301

JP (1968) "Bergh, Marthinus Adrianus" and "Bergh, Olof Martin(i)" in Dictionary of South African Biography vol 1 (Cape Town): 52-53 and 53-54

Kehoe, Marsely L (2015) "Dutch Batavia: Exposing the hierarchy of the Dutch colonial city" J of the Historians of Netherlandish Art 7: 1-35

Kitchin, SB (1916) “The Honourable FW Reitz” SALJ 33: 239-243

Kitshoff, MC (1977) "Fleck, Christiaan" in Dictionary of South African Biography vol 3 (Cape Town): 300

Knappert, L (1927) "Twee bezoeksreizen in den Oostelijken Ned Ind Archipel 1821-1825" Nederlands archief voor kerkgeschiedenis 20: 81-120

Knight, G Roger (2014) Sugar, Steam and Steel: The Industrial Project in Colonial Java, 18301885 (Adelaide)

Koning, Jacobus (1832) Leven van Jan Carel Josephus van Speijk (The Hague)

Kortlang, J (comp) (2007) Inventaris van het archief van de Weeskamer van Batavia, Arsip Nasional Republik Indonesia [ANRI], Jakarta / Nasionaal Archief, Den Haag (The Hague)

Kotzé, CR (1977) "Denijssen, Daniël” in Dictionary of South African Biography vol 3 (Cape Town): 207-208

Kotzé, CR (1981a) "Neethling, Johannes Henoch" in Dictionary of South African Biography vol 4 (Pretoria): 401-402

Kotzé CR (1981b) “Truter, Petrus Johannes” in Dictionary of South African Biography vol 4 (Pretoria): 663-664 
La Bree, SJ (nd) De rechterlijke organisatie en rechtsbedeling te Batavia in de xvii e eeuw (Rotterdam)

Lev, Daniel S (1985) "Colonial law and the genesis of the Indonesian state" Indonesia 40: 57-74

McAleer, John (2013) “"The key to India': Troop movements, Southern Africa, and Britain's Indian Ocean world, 1795-1820" International History Review 35: 294-316

McKenzie, Kirsten (1999) "Women's talk and the colonial state: The Wylde scandal, 1831-1833" Gender \& History 11: 30-53

McKenzie, Kirsten (2015) “"The laws of his own country': Defamation, banishment and the problem of legal pluralism in the 1820s Cape colony" $J$ of Imperial and Commonwealth History 43: 787-806

Milton, Giles (1999) Nathaniel's Nutmeg: How One Man's Courage Changed the Course of History (London)

Moll, JC (1977) "Die optrede en uitlatings van FW Reitz in Europa na die Anglo-Boereoorlog" SA Historical J 9: 30-38

Moll, JC (ed) (1978) FW Reitz - Outobiografie (Cape Town)

M Po (1972) "De Wet, Olof Godlieb" in Dictionary of South African Biography vol 2 (Cape Town): 191-192

Niemeijer, Hendrik E (2007) "The central administration of the VOC government and the local institutions of Batavia (1619-1811) - An introduction" in Hendrik E Niemeijer et al The Archives of the Dutch East India Company (VOC) and the Local Institutions in Batavia (Jakarta) (Leiden): 61-86

Nilant, FGE \& Potgieter, M (1981) “Truter, Oloff Johannes (John)” in Dictionary of South African Biography vol 4 (Pretoria): 661-662

Pama, C (1983) Die Groot Afrikaanse Familienaamboek (Cape Town)

Peires, JB (1989) “The British and the Cape, 1814-1834” in Richard Elphick \& Hermann Giliomee (eds) The Shaping of South African Society, 1652-1840 (Cape Town): 472-518

Phillips, H (1980) "Cape Town in 1829" Contree 8: 5-11

Pols, Hans (2011) "Notes from Batavia, the Europeans' graveyard: The nineteenth-century debate on acclimatization in the Dutch East Indies" J of the History of Medicine and Allied Sciences 67: $120-148$

Potgieter, M (1981) "Berrangé, Daniel Frederik" in Dictionary of South African Biography vol 4 (Pretoria): 27

Quinton, JC (1987) “Denyssen, Petrus Johannes" in Dictionary of South African Biography vol 5 (Pretoria): 185-186

Reinsma, R (1966) “Uit de aantekeningen van een oud-Indisch ambtenaar” Bijdragen tot de taal-, land-en volkenkunde 122: 229-254

Reitz, Conrad Hjalmar (1964) The Reitz Family. An Annotated Bibliography (Cape Town)

Reitz, FW (1900) A Century of Wrong (London)

RFMI (1968) "De Wet, Johannes" in Dictionary of South African Biography vol 1 (Cape Town): 240-241

Roberts, AA (1942) A South African Legal Bibliography (Pretoria)

Ross, Robert (1983) “The rise of the Cape gentry” J of Southern African Studies 9: 193-217 
Sachs, Albie (1973) Justice in South Africa (London)

Salverda, Reinier (2009) "Doing justice in a plural society: A postcolonial perspective on Dutch law and other legal traditions in the Indonesian archipelago, 1600-present" Dutch Crossings. J of Low Countries Studies 33: 152-170

Schulze, WG (2010) ““One JP de Wet'. South Africa's first judicial export?” Fundamina. A J of Legal History 16(2): 98-120

Schutte, GJ (1977) "Fagel, Baron Francois Willem" in Dictionary of South African Biography vol 3 (Cape Town): 283-284

South African Genealogies (2003) vol 9 (Ra-Ron) (Stellenbosch)

Stapel, FW (1932) "Bijdragen tot de geschiedenis der rechtspraak bij de Vereenigde Oostindische Compagnie" Bijdragen tot de taal-, land-en volkenkunde van Nederlandsch-Indië 89: 41-74

Sturgis, James (1983) “Anglicisation at the Cape of Good Hope in the early nineteenth century" $J$ of Imperial \& Commonwealth History 11: 5-32

Taylor, Jean Gelman (2009) The Social World of Batavia. Europeans and Eurasians in Colonial Indonesia 2 ed (Madison, Wis)

Theal, George McCall (ed) (1897-1905) Records of the Cape Colony 36 vols (Cape Town)

Toe Water, Jan Herman (1882) Over de rechterlijke inrichting in Nederlandsch Oost-Indië (doctoral thesis, University of Leiden)

Van den Bergh, GCJJ, Spruit, JE \& Van de Vrugt, M (eds) (1986) Rechtsgeleerd Utrecht. Levensschetsen van elf hoogleraren uit driehonderdvijftig jaar Faculteit der Rechtsgeleerdheid in Utrecht [Stichtse historische reeks 11] (Linschoten)

Van den Heever, FP (Toon) (1963) Introduction to the Civil Law of the Netherlands (Pretoria)

Van der Aa, AJ (1854) Biographisch woordenboek der Nederlanden vol 2, available at http://www. dbnl.org (accessed 16 Mar 2016)

Van der Brug, PH (1997) "Malaria in Batavia in the 18th century" Tropical Medicine and International Health 2: 892-902

Van der Kloot, MA van Rhede (1891) De gouverneurs-generaal en commissarissen-generaal van Nederlandsch-Indie 1619-1888 (The Hague)

Van Dissel, Anita (2015) "Pioneering in Southeast Asia in the first half of the nineteenth century" in Cátia Atunes \& Jos Gommans (eds) Exploring the Dutch Empire: Agents, Networks and Institutions 1600-2000 (London): 43-58

Van Huyssteen, LF (1989) “Kaapse strafregspraak vanaf ongeveer 1807-1827: 'n Voorlopige evaluering" SA J of Criminal Justice 2: 286-298

Van Huyssteen, Louis (1994) "Some notes on Roman-Dutch law at the Cape under British rule. Evaluation of a few general principles of the law of contract as applied by the Court of Justice between 1806 and 1827" Tijdschrift voor rechtsgeschiedenis 62: 357-365

Van Ittersum, Justine Julia (2016) "Debating natural law in the Banda islands: A case study in Anglo-Dutch imperial competition in the East Indies, 1609-1621" History of European Ideas 10: $1-38$

Van Niekerk, Gardiol (2015) "Multilingualism in South African courts: The legislative regulation of language in the Cape during the nineteenth century" Fundamina. A J of Legal History 21(2): $372-392$ 


\section{THE LIFE AND TIMES OF CAPE ADVOCATE DIRK GYSBERT REITZ}

Van Reenen, Jacobus (1927) Jacob van Reenen and the Grosvenor Expedition of 1790-1791 [Van Riebeek Society Publications no 8] (Cape Town), translated and annotated by PR Kirby as The Wreck of the Grosvenor (Johannesburg, 1958)

Visagie, GC (1969) Regspleging en Reg aan die Kaap van 1652 tot 1806 (Cape Town)

Vollgraaff, Heléne (2004) "Finding Marie: A search for the true Marie Koopmans-De Wet" Quarterly Bulletin of the National Library of South Africa 58: 129-139

Vreede-De Stuers, Cora (1996) “Adriana. Een kroniek van haar Indische jaren, 1809-1840" Bijdragen tot de taal-, land-en volkenkunde 152: 74-108

Williams, Gavin (2013) "Who, where, and when were the Cape gentry?" Economic History of Developing Regions 28: 83-111

Wagenaar, Gerard (1976) Johannes Gysbertus van Reenen-Sy Aandeel in die Kaapse Geskiedenis tot 1806 (MA thesis, University of Pretoria)

Ward, Kerry (2009) Networks of Empire: Forced Migration in the Dutch East India Company (Cambridge)

Wildenboer, L (2010) "The origins of the division of the legal profession in South Africa: A brief overview" Fundamina. A J of Legal History 16(2): 199-225

\section{Case law}

Cockerell v Dickens (1840) 3 Moore 99, 13 ER 45; (1840) 2 Moore Ind App 353, 18 ER 343

Colonial Government v Fitzroy (1830) 1 Menzies 492

Durr, In re. Orphan Chamber qq Minor Heirs in re Durr v Van Reenen (1832) 1 Menzies 565

Insolvent Estate of Brink, In re. Vendue-Commissaries v Brink (1828) 1 Menzies 434

Insolvent Estate of Buisinné, In re. Croeser v Sequestrator and Attorney-General (1829) 1 Menzies 330

Insolvent Estate of Buisinné, In re. Van der Byl \& Meyer v Sequestrator and Attorney-General (1828) 1 Menzies 318

John Reitz, In the Goods of (1831) 3 Hagg Ecc 766, 162 ER 1337

Loedolff $v$ The Present Orphan Chamber and the Surviving Members of the Former Orphan Chamber (1830) 1 Menzies 486

MacDonald \& Another v Bell (1840) 3 Moore 315, 13 ER 129 (PC)

Orphan Chamber $v$ Sertyn \& Others (1831) 1 Menzies 25

Orphan Chamber v Truter, Attorney (1830) 1 Menzies 452

Phillips $v$ Thornton (1831) 3 Hagg Ecc 752, 162 ER 1332

[President and Members of the] Orphan Board v [Johannes Gysbertus] Van Reenen \& Bayley (1829) 1 Knapp 82, 12 ER 252

Reitz v Kock (1828) 1 Menzies 38 and 56

Wylde v Wylde (1835) 1 Menzies 269 


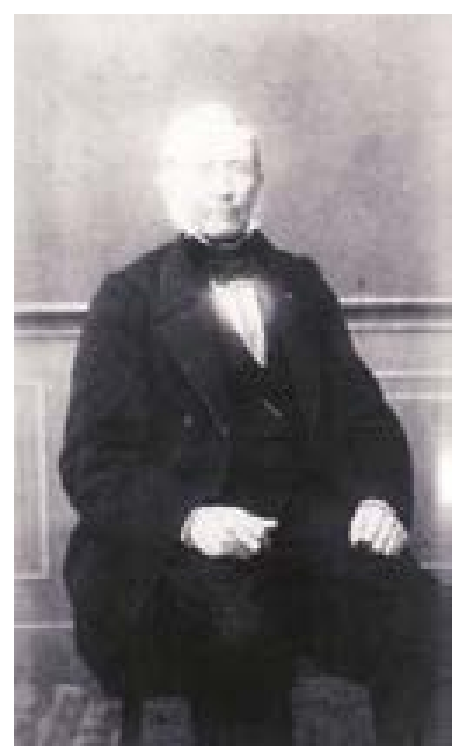

This overexposed photograph, uncaptioned but presumably of Dirk Gysbert Reitz, is reproduced next to the text describing his career in the genealogical website http:// ww.kloek-genealogie.nl/Reitz.htm (accessed 3 Nov 2015). 